FERNÁNDEZ, José. “Los apremios personales en la jurisprudencia del Tribunal Constitucional: un análisis crítico desde la dogmática de los principios y límites penales". Polít. crim. Vol. 13, № 25 (Julio 2018) Art. 10, pp. 350-386. [http://www.politicacriminal.cl/Vol_13/n_25/Vol13N25A10.pdf]

\title{
Los apremios personales en la jurisprudencia del Tribunal Constitucional: un análisis crítico desde la dogmática de los principios y límites penales ${ }^{1}$
}

\section{The Chilean Constitutional Court decisions on Debtors' Prisions: a Critical Analysis based on the Principles and Limits of Criminal Law}

\author{
José Ángel Fernández Cruz \\ Doctor en Derecho. Profesor de Derecho penal de la Universidad Austral de Chile \\ josefernandez@uach.cl \\ Emilio José Boutaud Scheuermann \\ Licenciado. Profesor ayudante de la Universidad Austral de Chile \\ emilioboutaud@gmail.com
}

\section{Resumen}

El presente trabajo analiza la constitucionalidad de los apremios personales en el derecho chileno desde la óptica de los principios y límites al ius puniendi. Para ello, se analizará la jurisprudencia de nuestro Tribunal Constitucional al respecto, con el fin de reconstruir sus líneas argumentales relativas a la naturaleza jurídica de los apremios personales, la aplicación del juicio constitucional de proporcionalidad y otras garantías penales, tales como los principios del debido proceso. Por último, se concluye planteando algunas críticas y propuestas legislativas, tomando como referencia la dogmática de los principios y límites penales y los tratados internacionales sobre derechos humanos.

Palabras clave: Apremios personales, límites al ius puniendi, principio de proporcionalidad.

\begin{abstract}
This paper analyzes the constitutionality of so-called apremios personales (Debtor's Prison) in Chilean law from the criminal constitutional limits' point of view. To do this, it will be examined the jurisprudence of the Constitutional Court of Chile in order to reconstruct their legal opinions on the legal nature of Debtor's Prison, the constitutional proportionality test and other criminal constitutional limits, such as the Due Process Clause. Finally, we realize a critical approach of this cases-law and make some legislative proposals taking as a reference the constitutional theory of criminal law and International Human Rights Treaties.
\end{abstract}

Key words: debtors' prisons, limits of criminal law, constitutional proportionality test.

\footnotetext{
${ }^{1}$ El presente estudio toma como referencia dos estudios previos realizados en el marco del Proyecto Fondecyt Regular No 1130076: FERNÁNDEZ CRUZ, José Ángel, “Tribunal Constitucional y Derecho Penal: un análisis crítico", Estudios constitucionales, vol.12 n.2 (2014), pp. 187-238; BOUTAUD SCHEUERMANN, Emilio José, La constitucionalidad de los apremios personales en la jurisprudencia del Tribunal Constitucional. Memoria para optar al grado de licenciado en ciencias jurídicas y sociales, FERNÁNDEZ CRUZ, José Ángel (Prof. patrocinante), (2014), pp. 1-72, disponible http://cybertesis.uach.cl/tesis/uach/2014/fjb778c/doc/fjb778c.pdf
} 
Polít. crim. Vol. 13, No 25 (Julio 2018) Art. 10, pp. 350-386.

[http://www.politicacriminal.c1/Vol_13/n_25/Vol13N25A10.pdf]

\section{Introducción}

Un conjunto de leyes del ordenamiento jurídico en materias de diversa índole (tributaria, familiar, seguridad social, etc.) permiten a los tribunales de justicia decretar como medida de apremio el arresto de una persona con el fin de impulsarle a cumplir una obligación. Ello se traduce en una privación, en principio, breve, de la libertad personal del afectado y, en el caso de que cumpla con dicha obligación, el arresto finaliza.

Con independencia de la naturaleza jurídica de los apremios personales, al encontrarnos ante una institución limitativa del derecho fundamental a la libertad personal se plantea la cuestión si le son aplicables los principios y límites reconocidos por la dogmática de los principios y límites penales. En un Estado democrático de Derecho, la Constitución es la norma de máxima jerarquía que estatuye los parámetros de validez de las normas jurídicas. En el ámbito penal, estos criterios se expresan en límites al ius puniendi consagrados, principalmente, dentro del catálogo normas adscritas a disposiciones de derecho fundamental. Así, toda intervención legislativa, para ser válida debe cumplir no solo con los procedimientos previstos para su dictación (validez formal), sino también con el contenido que exige el respeto a los derechos fundamentales de las personas (validez material). A ello deben sumarse las garantías establecidas en los tratados internacionales sobre derechos humanos que también consagran límites al ius puniendi.

Así, dos principios cobran vital importancia en materia de apremios ilegítimos: el debido proceso y del principio de proporcionalidad. En virtud del primero, se requiere que la imposición de una pena vaya acompañada de un conjunto de garantías, que otorguen al acusado la posibilidad de defenderse adecuadamente. Mientras que el segundo brinda un test de constitucionalidad tendiente a descartar la arbitrariedad en el ejercicio del poder punitivo, requiriendo que una limitación a un derecho fundamental sea adecuada, necesaria y proporcionada para la consecución de un fin legítimo.

La aplicación de apremios de arresto plantea un conflicto constitucional entre los derechos fundamentales a la libertad personal y a la seguridad individual del afectado y el interés, público o privado, de obtener el cumplimiento de una obligación contenida en una resolución judicial. Este conflicto ha llegado a conocimiento del Tribunal Constitucional (en adelante TC) a propósito de requerimientos de inaplicabilidad por inconstitucionalidad, que han puesto en entredicho la constitucionalidad de los apremios personales, invocando disposiciones de derecho interno relativas al debido proceso, el derecho a la libertad personal y seguridad individual, etc., así como de derecho internacional relativas a la proscripción de la prisión por deudas. Además, dicho tribunal ha aplicado el principio o juicio de constitucionalidad de proporcionalidad para dirimir los conflictos entre derechos fundamentales y bienes o intereses de relevancia constitucional que se presentan en estas peculiares formas de privación de libertad.

El presente trabajo tiene como objetivo principal reconstruir, desde una perspectiva crítica, la jurisprudencia del Tribunal Constitucional relativa a los apremios personales. Para ello, se seguirá la siguiente estructura: en la primera parte se examinará el concepto, clasificación, y 
FERNÁNDEZ, José. "Los apremios personales en la jurisprudencia del Tribunal Constitucional: un análisis crítico desde la dogmática de los principios y límites penales”.

naturaleza jurídica de los apremios personales; en la segunda parte se expondrá la jurisprudencia del Tribunal Constitucional sobre apremios personales; mientras que en la tercera parte se analizará críticamente dicha jurisprudencia. Por último, como objetivo secundario, se formularán de manera sucinta una serie de propuestas de reforma legislativa y unos criterios de interpretación, ambos destinados a adecuar estas medidas a los principios y límites penales reconocidos directa o implícitamente en nuestra Constitución.

\section{Los apremios personales.}

\subsection{Concepto y clasificación de los apremios personales en el derecho positivo chileno.}

Diversas normas del derecho chileno facultan a los tribunales de justicia para decretar apremios en contra de una persona ante el incumplimiento de alguna prestación u obligación que le era exigible. Dentro de estos apremios existe el denominado "apremio personal", que se caracteriza por recaer sobre la persona del afectado, específicamente, sobre su libertad de desplazamiento, característica que los distingue de los "apremios reales", por ejemplo, el embargo o la multa, en el que la limitación de los derechos recae sobre el patrimonio del afectado.

El apremio de arresto implica una privación o restricción del derecho fundamental a la libertad personal y seguridad individual. Por esta razón, la Comisión de Estudios de la Nueva Constitución (en adelante CENC), al abordar las garantías que rodean a las diferentes modalidades en la que se puede concretar una privación de la libertad personal, decidió hacer extensivas las garantías del "detenido" al "arrestado". ${ }^{2}$ Así, en la sesión 107, el comisionado Alejando Silva Bascuñán propuso incluir la expresión "arrestado” en el entonces artículo 13.

No obstante, los comisionados distinguieron el arresto de la detención, siendo particularmente aclaratorias las palabras de Jorge Ovalle, para quien el arresto es:

"Una institución que no forma parte propiamente del proceso criminal, sino que es una forma de apremio en general, para obligar a determinados individuos a adoptar la conducta socialmente necesaria en un momento dado. Así, por ejemplo, en las leyes tributarias a ciertos deudores de compraventa se les arresta mientras no paguen el tributo que han retenido. Y a los deudores de pensiones alimenticias se les arresta mientras no paguen las pensiones a que han sido condenados. Tienen en común con la detención el hecho de que son provisionales.

En general, el arresto es una privación provisional de la libertad sujeta al cumplimiento de un acto por parte del arrestado. (...) En cambio, la detención es una de las medidas que se configura en el proceso criminal con el objeto de asegurar la persona del eventual delincuente, y su destino no depende de un acto que realice el detenido (...)".3

\footnotetext{
${ }^{2}$ ACTAS DE LA COMISIÓN DE ESTUDIO DE LA NUEVA CONSTITUCIÓN, Sesión 107, 18 de marzo de 1975, pp. 636 - 666.

${ }^{3}$ ACTAS DE LA COMISIÓN DE ESTUDIO DE LA NUEVA CONSTITUCIÓN, Sesión 107, cit. nota n 2, pp. $643-644$.
} 
Polít. crim. Vol. 13, № 25 (Julio 2018) Art. 10, pp. 350-386.

[http://www.politicacriminal.cl/Vol_13/n_25/Vol13N25A10.pdf]

De lo anterior, se desprende que el apremio de arresto fue entendido como una medida coercitiva excepcional, breve y desvinculada del ámbito penal ${ }^{4}$, sin perjuicio de los cuestionamientos que, como veremos con posterioridad, puedan efectuarse al cumplimiento de estas características. ${ }^{5}$

Los apremios, como hemos mencionado, constituyen medidas que tienen como finalidad el cumplimiento de una resolución judicial y que podemos agrupar en tres grupos: los que contemplan el incumplimiento de una obligación pecuniaria; los que contemplan el incumplimiento de otro tipo de obligaciones; y, por último, aquellos destinados a favorecer el desarrollo de un proceso judicial.

1.1.1. Apremios personales destinados al cumplimiento de resoluciones judiciales que condenan al pago de una obligación pecuniaria.

Estos apremios son decretados usualmente una vez que la fase de discusión de un proceso ha concluido y, por tanto, se encuentra en fase de ejecución, o luego de notificar al afectado de que se ha iniciado un proceso en su contra para exigir el cumplimiento de una obligación.

Pertenecen a esta clase los apremios contemplados en:

$>$ El artículo 12 de la Ley 17.322, sobre Normas para la Cobranza de Cotizaciones, Aportes y Multas de las Instituciones de Seguridad Social, respecto del empleador que no consignare los aportes descontados o que debió descontar de la remuneración de sus trabajadores y sus reajustes e intereses penales;

Los artículos 14 y 15 de la Ley 14.908 sobre Abandono de Familia y Pago de Pensiones Alimenticias, respecto del alimentante que no hubiere cumplido su obligación alimenticia en la forma pactada u ordenada, hubiere dejado de pagar una o más de las pensiones decretadas, renunciare sin causa justificada a su trabajo después de la notificación de la demanda o enajenare sin autorización del juez bienes sobre los cuales se hubiere fijado como pensión alimenticia un derecho de usufructo, uso o habitación;

El Título I del Libro II del Código Tributario (arts. 93 a 96) respecto del contribuyente que tuviere obligaciones tributarias impagas o se hubiere retardado en enterar impuestos sujetos a retención o recargo $\left(\mathrm{N}^{\circ} 11\right.$ art. 97 Código Tributario);

\footnotetext{
${ }^{4}$ Estas características han sido reconocidas por el Tribunal Constitucional en varias sentencias. Así, por ejemplo, en la sentencia Rol 576-06, del 24 de abril de 2007, en cuyo considerando 18 el Tribunal señaló: "Que (...) del sentido natural y obvio de la expresión puede afirmarse que el arresto, como medida de apremio no referida necesariamente al proceso penal, fue expresamente contemplado en la Constitución Política de la República como una restricción o limitación a la libertad personal, sujetándolo a dicho régimen jurídico, de modo que solo pudiera adoptarse de manera excepcional con plena observancia de las garantías constitucionales (...)".

Por su parte, la doctrina ha puesto de relieve la desvinculación del arresto del proceso penal. Por ejemplo, Hernán Molina sostiene que "[e]l arrestado es el individuo que está privado de libertad en virtud de una medida de apremio o de seguridad, no vinculada a un proceso penal". MOLINA, Hernán, Derecho Constitucional, Santiago: Legal Publishing, 2010, p. 214. En el mismo sentido, VERDUGO, Mario., et al, Derecho Constitucional, Tomo I, Santiago: Editorial Jurídica de Chile, 1999, p. 238.

${ }^{5}$ Véase el epígrafe 3 de este estudio.
} 
FERNÁNDEZ, José. "Los apremios personales en la jurisprudencia del Tribunal Constitucional: un análisis crítico desde la dogmática de los principios y límites penales".

$>$ El artículo 32 inciso segundo de la Ley 18.695 Orgánica Constitucional de Municipalidades, sobre el alcalde que no dictare el correspondiente decreto alcaldicio que ordene el pago de una deuda del Municipio o Corporación Municipal; ${ }^{6}$

El artículo 28 del Decreto Ley 211 respecto del condenado al pago de una multa por el Tribunal de Defensa de la Libre Competencia que no acreditare su pago; ${ }^{7}$

Asimismo, el Código del Trabajo (en adelante, CT) contempla otras situaciones en que sería plausible decretar apremios de arresto en materia de ejecución de incumplimiento de obligaciones en materia laboral. Así, el artículo 465, en concordancia con lo dispuesto en el artículo 432, refiriéndose al cumplimiento de las sentencias, consagra la aplicación supletoria -siempre que no se vulneren los principios del procedimiento laboral y a falta de disposición expresa en el Código o en leyes especiales- de las normas contenidas en el Título XIX del Libro Primero del Código de Procedimiento Civil (en adelante CPC), dentro de las cuales se encuentra el apremio personal contemplado en el artículo 238. Por su parte, el artículo 473, tratándose de títulos ejecutivos laborales distintos a la sentencia ejecutoriada, consagra, bajo las mismas condiciones que el artículo 465, la aplicación supletoria de las normas contenidas en los títulos I y II del Libro Tercero ("Del Procedimiento Ejecutivo en las obligaciones de hacer y no hacer") del CPC, dentro de las cuales se encuentra el apremio personal descrito en artículo $543 .^{8}$

1.1.2. Apremios personales destinados a obtener el cumplimiento de otro tipo de resoluciones judiciales.

En estos casos la obligación incumplida no consiste en pagar una suma de dinero, sino en realizar otro tipo de conductas. Son de esta clase los apremios contemplados en las siguientes disposiciones legales:

El artículo 238 del CPC, tratándose del cumplimiento de resoluciones no comprendidas en los artículos anteriores del Título XIX del Libro Primero del CPC, es decir, que no sean sentencias o que siéndolo se encuadren dentro de la hipótesis del artículo 235, número 5, $\mathrm{CPC} ;{ }^{9}$

\footnotetext{
${ }^{6}$ Este artículo no establece un apremio, sino que regula su aplicación, precisando que “(...) tratándose de resoluciones recaídas en juicios que ordenen el pago de deudas por parte de una municipalidad o corporación municipal, y correspondiere aplicar la medida de arresto prevista en el artículo 238 del Código de Procedimiento Civil, esta solo procederá respecto del alcalde en cuyo ejercicio se hubiere contraído la deuda que dio origen al juicio".

${ }^{7}$ Este artículo establece que una vez cumplido el plazo de días hábiles que el afectado tiene para pagar la multa y este no acreditare su pago, el Tribunal deberá, de oficio o a petición de parte, y sin forma de juicio, apremiarlo del modo establecido en el artículo 543 del CPC.

${ }^{8}$ Con todo, la aplicación de apremios personales parece poco probable en atención a lo dispuesto en el artículo 471 de dicho código, que determina que, si no se ha pagado dentro de plazo, se procederá a trabar embargo sobre bienes muebles o inmuebles suficientes para el cumplimiento íntegro de la ejecución y sus costas.

${ }^{9}$ ANABALÓN, Carlos, Tratado Práctico de Derecho Procesal Civil Chileno: vol. 1, 2a Edición, Concepción: Librotec, 1966, pp. 298 y 299. Aunque conviene precisar que parte de la doctrina (Arancibia) ha restringido el ámbito de aplicación de este precepto al señalar que “(...) el artículo 238 del CPC no resulta aplicable a las sentencias que ordenan pagar una suma de dinero al Fisco, puesto que no se cumple con la condición exigida
} 
Polít. crim. Vol. 13, No 25 (Julio 2018) Art. 10, pp. 350-386.

[http://www.politicacriminal.cl/Vol_13/n_25/Vol13N25A10.pdf]

El artículo 543 del CPC, respecto del deudor de una obligación de hacer o de una obligación de no hacer cuando esta se convierta en la de destruir la obra hecha (Art. 544 CPC);

El artículo 227 inciso 3 del Código Civil, respecto del condenado por sentencia ejecutoriada a hacer entrega del hijo que no lo hiciere o se negare a hacerlo;

$>$ El artículo 41 de la Ley 18.287, respecto del conductor que injustificadamente impidiere el cumplimiento de la cancelación o suspensión de su licencia decretada por el Juez de Policía Local;

El artículo 292 del CT, respecto del empleador que se negare a dar cumplimiento cabal a la orden de reincorporación de un trabajador, o ante una nueva separación o no pago oportuno y debido de las remuneraciones y demás prestaciones laborales de un trabajador; ${ }^{10}$

El artículo 77 de la Ley 19.968, ante el incumplimiento de las medidas de protección adoptadas por un tribunal de familia;

El artículo 10 de la Ley 20.066, ante el incumplimiento de medidas cautelares o accesorias decretadas en el procedimiento por actos de violencia intrafamiliar no constitutiva de delito; $\mathrm{y}$,

El artículo 18 de la Ley 20.066, ante el incumplimiento de medidas cautelares, medidas accesorias y condiciones para la suspensión del procedimiento decretadas en el procedimiento por actos de violencia intrafamiliar constitutiva de delito.

1.1.3. Apremios personales destinados a favorecer el desarrollo de un proceso judicial.

Si bien también pretenden impulsar al cumplimiento de resoluciones judiciales, su finalidad principal es cautelar o resguardar la realización de determinadas diligencias en un proceso judicial o administrativo ${ }^{11}$. Por ejemplo, el artículo 33 inciso tercero del Código Procesal Penal (en adelante CPP) establece que:

“(...) Tratándose de los testigos, peritos u otras personas cuya presencia se requiriere, podrán ser arrestados hasta la realización de la actuación por un máximo de veinticuatro horas e imponérseles, además, una multa de hasta quince unidades tributarias mensuales". ${ }^{12}$

para su vigencia”. ARANCIBIA, Jaime, "Cumplimiento de sentencias que ordenan pagar una suma de dinero al Fisco", en: ARANCIBIA, Jaime; MARTÍNEZ, José; ROMERO, Alejandro (Coords.), Litigación Pública, Santiago: Thomson Reuters, 2011, pp. 515-557, p. 534.

${ }^{10}$ En este último supuesto, el apremio decretado pertenecería a la primera categoría puesto que estaría dirigido a impulsar el pago de obligaciones pecuniarias.

${ }^{11}$ Debe tenerse presente que impuesta esta privación de libertad al cumplimiento de la obligación (presentarse ante la autoridad requerida) ya no dependen de la voluntad del requerido.

12 Otros supuestos en que se faculta a los tribunales de justicia para decretar apremios destinados a asegurar investigaciones o fiscalizaciones que realizan órganos de la Administración del Estado: 
FERNÁNDEZ, José. “Los apremios personales en la jurisprudencia del Tribunal Constitucional: un análisis crítico desde la dogmática de los principios y límites penales".

\begin{abstract}
El mismo CPP también contempla el arresto respecto de los testigos legalmente citados que no comparecieren sin justa causa (art. 299). ${ }^{13}$
\end{abstract}

En consecuencia, los apremios personales deben distinguirse de las privaciones de libertad que contemplan otras normas con el fin de sustituir el pago de una multa previamente impuesta $^{14}$ o de reprimir o castigar abusos o faltas cometidos en las diferentes salas de tribunales (arrestos disciplinarios). ${ }^{15}$

- La Ley 20.417, en contra de las personas que la Superintendencia del Medio Ambiente hubiere citado a declarar que no concurran sin causa justificada (art. 29).

- El Código Tributario, cuando el contribuyente: no exhiba sus libros o entrabe la fiscalización del Servicio de Impuestos Internos, no compareciere sin causa justificada durante la recopilación de antecedentes habiéndosele citado dos veces, o no llevare contabilidad o los libros auxiliares exigidos (art. 95).

${ }^{13}$ Normas similares encontramos en otros cuerpos normativos:

- El CPC, ante: la negativa a prestar declaración o la entrega de respuestas no categóricas acerca de algún hecho relativo a la capacidad para parecer en juicio, la personería o el nombre y domicilio de sus representantes, por parte del sujeto al que se pretende demandar (art. 274); la renuencia a exhibir la cosa que ha de ser objeto de la acción que se trata de entablar o la negativa del tercero mero tenedor de un objeto a exhibirlo (art. 276); la negativa de aquel a quien se intenta demandar y que expone ser simple tenedor de la cosa a declarar el nombre y residencia de aquel a cuyo nombre la tiene o a exhibir el título de su tenencia (art. 282); la renuencia a exhibir, sin justa causa, instrumentos en poder de un tercero (art. 349); la negativa -injustificada- a declarar del testigo legalmente citado que comparece (art. 380); y, la no comparecencia del litigante rebelde al segundo llamado a absolver posiciones, sus respuestas evasivas o su negativa a declarar ante hechos no categóricamente afirmados en el pliego de posiciones (art. 394).

- La Ley 19.968, respecto del testigo legalmente citado que no compareciere sin justa causa (art. 34), y sobre el demandado o denunciado en el procedimiento de violencia intrafamiliar que no compareciere a la audiencia preparatoria (art. 95).

- La Ley 18.287 respecto del conductor que no concurriere a la citación o su domicilio registrado no correspondiere o fuere inexistente (art. 40 inciso segundo).

- El Código Orgánico de Tribunales respecto de las personas que tengan copias autorizadas de los protocolos o documentos pertenecientes a la notaría que se negaren a presentarse al tribunal (art. 438).

- El Decreto Ley 211 respecto de las personas que entorpezcan las investigaciones de la Fiscalía Nacional Económica en el ámbito de sus funciones (art. 42).

${ }^{14}$ Este tipo de privación de libertad-que en el derecho comparado figura dentro del catálogo de penas privativas de libertad, por ejemplo, en el artículo 35 del Código Penal de España-, tiene una doble finalidad, por una parte, compeler al pago de una multa previamente impuesta y, por otra, sustituir la pena de multa si el condenado no la paga. Pertenecen a esta clase las privaciones de libertad contempladas en:

- El artículo 23 de la Ley 18.287 que faculta al juez de policía local para decretar -por vía de sustitución y apremio- la reclusión o la prestación de servicios en beneficio de la comunidad del condenado al pago de una multa que no hubiere acreditado su pago. En conformidad al inciso tercero de este artículo, el pago de la multa permite dejar sin efecto estas medidas de sustitución y apremio.

- El artículo 49 inciso segundo del Código Penal respecto del condenado que no tuviere bienes para satisfacer la pena de multa y no estuviere de acuerdo en prestar servicios en beneficio de la comunidad; y,

- El artículo 52 inciso segundo de la Ley 20.000 respecto del sentenciado que no hubiere pagado una multa y no estuviere de acuerdo en asistir a programas de prevención, de tratamiento o de rehabilitación;

Excepcionalmente, en algunos casos, no se apremia previamente al afectado, sino que la multa se sustituye por el arresto. Es el caso, por ejemplo, del litigante beneficiario de pobreza que debe pagar una multa debido a que procedió con notoria malicia (artículo 591 del Código Orgánico de Tribunales).

${ }^{15}$ Son de esta clase los arrestos contemplados en: el Título XVI del Código Orgánico de Tribunales para reprimir o castigar los abusos que se cometieren dentro de la sala de despacho de los jueces de letras y las faltas que se cometieren ante la Corte Suprema y ante las Cortes de Apelaciones, mientras ejercen sus funciones (arts. 530 y 542) y, en el Código de Justicia Militar como pena, tratándose de faltas de disciplina (art. 430). 
Polít. crim. Vol. 13, № 25 (Julio 2018) Art. 10, pp. 350-386.

[http://www.politicacriminal.c1/Vol_13/n_25/Vol13N25A10.pdf]

\subsection{Naturaleza jurídica de los apremios personales: una manifestación de derecho penal ilegítimo.}

Las normas que establecen apremios de arresto, a pesar de no estar incorporadas al Código Penal ni al Código Procesal Penal, plantean la problemática acerca de su adscripción al derecho penal.

La postura tradicional de la doctrina ha sido considerar al apremio de arresto como una medida restrictiva de la libertad distinta a una pena. Así, para Cury:

“(...) $[\mathrm{N}]$ o constituyen penas las medidas coercitivas que el derecho privado o el derecho procesal autorizan a imponer en ciertos casos con el objeto de forzar al cumplimiento de una obligación o de deberes jurídicos, algunas de las cuales puede adoptar formas que la asemejan a la reacción punitiva, incluyendo privaciones breves de libertad. (...) La diferencia radica, ante todo, en la naturaleza y finalidad de estas instituciones. Mientras la pena es prevención general, las medidas descritas solo constituyen coacción para que se cumpla un hecho jurídicamente debido". ${ }^{16}$

Con todo, esta explicación no es del todo satisfactoria, razón por la cual, ha recibido cuestionamientos por parte de la doctrina. Por una parte, Humberto Nogueira ha advertido que el arresto "(...) no se encuentra suficientemente regulado en nuestro ordenamiento jurídico, pudiendo en una distorsión del mismo, transformarse en una forma de prisión, lo que no se ajusta a su naturaleza y fin ${ }^{17}$ '”. Por otra parte, Ramón Domínguez, sin cuestionar la naturaleza jurídica del apremio contemplado en el artículo 12 de la Ley 17.322, mantiene que ese sería un caso de prisión por deudas, proscrito por el artículo 7.7 de la Convención Americana de Derechos Humanos (en adelante CADH). ${ }^{18}$

Desde una perspectiva material, considerando que el derecho penal se caracteriza frente a otras normas por intervenir de manera intensa en la libertad del individuo, es posible cuestionar la naturaleza jurídica de la privación de libertad que sufre como apremio personal

${ }^{16}$ CURY, Enrique, Derecho Penal Parte General. Santiago: Ediciones Universidad Católica de Chile, 2005, p. 83. VERDUGO, Mario, et al, Derecho Constitucional, cit. nota no 4, p. 202, han señalado: “(...) [e]l arresto como medida de apremio se ordena a fin de que el afectado cumpla una prestación o realice determinada gestión ante los tribunales de justicia (pague una pensión alimenticia o preste declaración ante un tribunal) (...)”. En el mismo sentido, Etcheberry señala que en nuestra legislación a la palabra apremio se le atribuye "(...) el sentido de medidas que no son penas ni medios de investigación, sino que tienen por fin compeler a alguien a cumplir con ciertas obligaciones (...)". ETCHEBERRY, Alfredo, Derecho penal: Parte general, Tomo I, Santiago: Editorial Jurídica de Chile, 1998, p. 67.

17 NOGUEIRA, Humberto, Derechos fundamentales y garantías constitucionales: Tomo II, Santiago: Librotecnia, 2007, p. 422.

${ }^{18}$ DOMÍNGUEZ, Ramón, “Apremio por no pago de imposiciones. ¿Prisión por deudas?”, Revista de Derecho Universidad de Concepción, No 214 (2003), pp. 188-194, p. 190. En sentido contrario, véase LATANA, Gabriela, "El apremio de arresto contemplado en el artículo 12 de la Ley 17.322 ¿Prisión por deudas?”, Revista de Derecho (Universidad de Concepción), 2013, pp.143-155. Sobre la prisión por deudas, véase, además, GARCÍA, Ana, “Justicia constitucional y prohibición internacional de la prisión por deudas”, en: Núñez, Manuel (Ed.), La internacionalización del derecho público. Actas XLII Jornadas Chilenas de Derecho Público, Santiago: Thomson Reuters, 2015, pp. 471-491, p. 472, quien sostiene que "La prohibición de la prisión por deudas tiene por objeto garantizar la libertad individual, de modo que las personas no sufran restricción de su libertad por el incumplimiento de obligaciones cuyo origen se encuentre en relaciones de origen civil". 
FERNÁNDEZ, José. “Los apremios personales en la jurisprudencia del Tribunal Constitucional: un análisis crítico desde la dogmática de los principios y límites penales".

quien incumple una resolución judicial y, por tanto, sostener que estas normas pertenecen al derecho penal ${ }^{19}$. La cuestión, por tanto, preliminar no es tanto dilucidar si los apremios tienen una estructura similar a un delito, sino si estas figuras, desde una perspectiva material, pertenecen al derecho penal. En este sentido, debe advertirse que la pena no constituye la única consecuencia jurídico penal. Así y modo de ejemplo, podemos mencionar las manifestaciones del derecho penal de tercera vía reguladas en el CPP (acuerdos reparatorios, suspensión condicional del procedimiento). Incluso, desde una concepción amplia del derecho penal que englobe el derecho procesal penal, la prisión preventiva constituye también una consecuencia jurídica penal.

Dilucidada esta cuestión previa, podemos preguntarnos si los apremios constituyen, materialmente, ilícitos penales. Así, podemos afirmar que las normas sobre apremios personales tienen una estructura normativa similar a la establecida en un delito. ${ }^{20}$ La conducta típica sería el incumplimiento de una resolución judicial (omisión), ${ }^{21}$ el bien jurídico protegido la administración de justicia y la consecuencia jurídica la privación de libertad del infractor. ${ }^{22}$ Además, se contemplaría como causa de exclusión de la punibilidad, una excusa absolutoria, consistente en el cumplimiento de la prestación exigida, hecho que haría cesar el "apremio". ${ }^{23}$ En este sentido, en el derecho comparado no han existido mayores

\footnotetext{
${ }^{19}$ Existe consenso en la doctrina nacional que lo que determina que una norma sea penal no es su consagración en el Código Penal y que por tanto pueden existir normas penales fuera de este. Por ejemplo, Eduardo Novoa reconoce que "(...) en los cuerpos legales destinados a legislar sobre materias jurídicas no penales suelen encontrarse preceptos sancionatorios especiales, de carácter genuinamente penal, que por su naturaleza especialísima o por haber advertido el legislador su necesidad después de redactado el C. Penal, quedan injertados en aquellos". Así, "[p]or lo que se refiere al Derecho Procesal Civil, el Código Penal sanciona diversos hechos atentatorios contra bienes jurídicos que aquel reconoce (Arts. 209, 212, 223 a 226 y $469 \mathrm{~N}^{\circ} 6$ del C. Penal). También en el Código de Procedimiento Civil se encuentran algunas disposiciones de carácter penal (p. ej. los Arts. 240 y 444) o que hacen referencia a hechos punibles (Art. 297)". NOVOA, Eduardo, Curso de Derecho penal chileno: Parte general, Tomo I, Santiago: Editorial Jurídica de Chile, 2005, pp. 54 y 59.

${ }^{20}$ Por ejemplo, en el caso del artículo 12 de la Ley 17.322, el supuesto de hecho de la norma sería la no consignación por parte del empleador de las sumas descontadas o que debió descontar de la remuneración de sus trabajadores y sus reajustes e intereses penales, dentro del término de quince días, contado desde la fecha del requerimiento de pago si no opuso excepciones, o desde la fecha de la notificación de la sentencia de primera instancia que niegue lugar a ellas, mientras que la consecuencia jurídica sería el apremio de arresto hasta por quince días.

${ }^{21} \mathrm{El}$ incumplimiento de resoluciones judiciales puede ser constitutivo de un delito de desacato, contemplado en el artículo 240 del CPC. La comprensión del incumplimiento de ciertas resoluciones judiciales como delitos de mera desobediencia plantea el problema de su delimitación con este delito. Al respecto Héctor Hernández ha señalado que “(...) [t]odo sugiere que ante el incumplimiento de una resolución judicial al sistema de apremios y al delito de desacato le corresponden funciones complementarias, en términos de que el ámbito de aplicación del delito de desacato comienza donde termina el de los apremios". HERNÁNDEZ, Héctor, "Alcances del delito de desacato en el contexto de la Ley de Violencia Intrafamiliar", Informes en Derecho, Santiago: Defensoría Penal Pública, 2011, pp. 1- 9, pp. 8 y ss.

${ }^{22}$ Como veremos, en posterior apartado, los apremios ilegítimos, tildados en principio como manifestaciones de la denominada prisión por deudas, se encuentran en proceso de transformación por parte de la jurisprudencia del TC en delitos de desobediencia (...)". FERNÁNDEZ, José, "Tribunal Constitucional y derecho penal: un estudio crítico", Revista Estudios Constitucionales, N² (2014), pp. 187-238, p. 228.

${ }^{23}$ FERNÁNDEZ, “Tribunal Constitucional”, cit. nota n 23, p. 227.
} 
Polít. crim. Vol. 13, № 25 (Julio 2018) Art. 10, pp. 350-386.

[http://www.politicacriminal.c1/Vol_13/n_25/Vol13N25A10.pdf]

complicaciones en tipificar penalmente el incumplimiento de obligaciones decretadas en una sentencia. $^{24}$

También debemos tener presente la posibilidad de que la privación de libertad en la aplicación de algunos apremios personales, si se considera el carácter renovable de estas medidas, puede, de facto, ser mayor que la contemplada en una gran parte de delitos. ${ }^{25}$

No obstante, y con independencia de si estamos, desde una perspectiva material, ante normas penales, debe determinarse, conforme con la jurisprudencia del TC en materia del derecho administrativo sancionatorio, qué principios o garantías le son aplicables. No debemos perder de vista, que tanto la prisión provisional como la pena de prisión se imponen por tribunales con competencia penal, en un procedimiento provisto de las garantías contempladas en el Código Procesal Penal.

\section{Jurisprudencia del Tribunal Constitucional sobre la constitucionalidad de los apremios personales.}

La aplicación de apremios personales plantea un conflicto entre distintos bienes jurídicos o valores protegidos por la Constitución, tales como el derecho a la libertad personal y seguridad individual (Art. $19 \mathrm{~N}^{\circ} 7 \mathrm{CPR}$ ), el derecho al debido proceso (Art. $19 \mathrm{~N}^{\circ} 3$ inciso sexto), el derecho de propiedad (Art. 19 N²4 CPR), la protección del trabajo (art. $19 \mathrm{~N}^{\circ} 16$ ) y el bien común (Art. 1 inciso $4^{\circ} \mathrm{CPR}$ ). Este conflicto constitucional puede expresarse en los siguientes términos: ¿cómo conciliar las facultades que la Constitución reconoce a la jurisdicción para "ejecutar lo juzgado" (dentro de las cuales se insertarían los apremios) con los derechos a la libertad personal y seguridad individual del sentenciado?

El TC se ha pronunciado sobre este conflicto a raíz de requerimientos de inaplicabilidad por inconstitucionalidad. ${ }^{26}$ La mayoría de estos requerimientos se refieren a apremios destinados a obtener el cumplimiento de una obligación pecuniaria. A continuación, se examinarán las

${ }^{24}$ Así, el artículo 227 del Código Penal español sanciona al “(...) que dejare de pagar durante dos meses consecutivos o cuatro meses no consecutivos cualquier tipo de prestación económica en favor de su cónyuge o sus hijos, establecida en convenio judicialmente aprobado o resolución judicial en los supuestos de separación legal, divorcio, declaración de nulidad del matrimonio, proceso de filiación, o proceso de alimentos a favor de sus hijos (...)" (inciso primero), y al “(...) que dejare de pagar cualquier otra prestación económica establecida de forma conjunta o única en los supuestos previstos en el apartado anterior” (inciso segundo), con la pena de prisión de tres meses a un año o multa de seis a 24 meses. A su vez, el artículo 149 del Código Penal peruano sanciona a quien "omite cumplir su obligación de prestar los alimentos que establece una resolución judicial", con "pena privativa de libertad no mayor de tres años, o con prestación de servicio comunitario de veinte a cincuentidós jornadas, sin perjuicio de cumplir el mandato judicial".

${ }^{25}$ Cuánto más se extienda el apremio de arresto, es más probable que se produzcan una serie de consecuencias negativas asociadas a las penas privativas de libertad de corta duración, ya que se suspende de forma súbita las actividades del individuo en su plano familiar, social y laboral, a lo que suma el efecto estigmatizante que trae aparejado para su vida posterior en libertad. En Chile, GARRIDO, M, Derecho penal: Parte general, Tomo I, Santiago: Editorial Jurídica de Chile, 2001, p. 283.

${ }^{26}$ Antes de la reforma constitucional del año 2005, el mecanismo jurisdiccional mayormente empleado por los afectados que consideraban que los arrestos decretados como medida de apremio constituían una manifestación de la prisión por deudas, era el recurso de amparo. Algunos de estos recursos fueron acogidos, pudiendo apreciarse un dispar criterio en sentencias de las Cortes de Apelaciones y de la Corte Suprema frente a casos similares. Para un análisis más detallado, DOMÍNGUEZ, "Apremio", cit. nota n 18, pp. 188-194. 
FERNÁNDEZ, José. “Los apremios personales en la jurisprudencia del Tribunal Constitucional: un análisis crítico desde la dogmática de los principios y límites penales".

principales consideraciones de las causas en que el TC ha dictado sentencia de fondo prestando especial atención a la doctrina del TC respecto a la naturaleza jurídica de los apremios personales, la aplicación del juicio de proporcionalidad y la concurrencia de otras garantías constitucionales penales.

\subsection{Naturaleza jurídica de los apremios personales.}

En la mayoría de los fallos objeto de nuestro análisis, el TC, como cuestión previa, se ha referido a la naturaleza jurídica de los apremios personales, caracterizándolos como una medida compulsiva que implica una privación temporal de la libertad personal del afectado. ${ }^{27}$

Asimismo, con el fin de diferenciarlos de los apremios ilegítimos, proscritos por el artículo 19, número 1, inciso final CPR, el TC ha señalado que se entiende por apremio legítimo "el impuesto con justicia, que es proporcionado a la consecución de una finalidad lícita, secuela de una decisión de autoridad competente en un proceso justo", ${ }^{28}$

Respecto de la distinción entre los apremios y otras formas de privación de libertad el TC ha reconocido que:

“(...) $[\mathrm{N}] \mathrm{o}$ es lo mismo prisión o detención -expresiones con un claro sentido penal o procesal penal-que arresto. Las penas de encierro, privativas o restrictivas de libertad, y el tiempo de detención imputable a su cumplimiento por ser de idéntica naturaleza, están fundadas en la comisión de un delito y tienen por fin su retribución o expiación, la disuasión social o prevención general y la corrección personal del sancionado o prevención especial. Nada de eso concurre en el arresto, el que no tiene ni naturaleza ni fin penales. Es, en cambio, una medida de apremio, cuya finalidad es presionar para el cumplimiento de una obligación legal, de modo tal que, cumplida dicha obligación, el arresto cesa; lo que no ocurre con las sanciones penales". ${ }^{29}$

Así en el considerando 17 de las sentencias Rol 2743-14 y Rol 2791-15, el TC advierte que, aunque el artículo $102 \mathrm{~F}$ de la Ley $19.968^{30}$ “(...) use la voz detención, se está refiriendo al arresto, por parte de la fuerza pública, de un adolescente rebelde a concurrir a la citación que

\footnotetext{
27 Tribunal Constitucional, Rol 519-06, 5 de junio de 2007, considerando 17. En el mismo sentido sentencias Rol 576-06, 24 de abril de 2007, considerando 17; Rol 1006-07, 22 de enero de 2009, considerando 19; y Rol 2102-11, 27 de septiembre de 2012, considerando 37.

${ }^{28}$ CEA, José, Derecho Constitucional Chileno. Tomo II: Derechos, deberes y garantías, Santiago: Ediciones Universidad Católica de Chile, 2003, p. 113. A modo de ejemplo; Tribunal Constitucional, Rol 576-06, 24 de abril de 2007, considerando 36.

29 Tribunal Constitucional, Rol 2102-11, 27 de septiembre de 2012, considerando 36. A su vez, en el considerando 5 de la sentencia Rol 1971-11, de 13 de diciembre de 2011, el TC sostuvo: “Que el arresto a que pueden dar lugar las normas cuestionadas, es una medida de apremio que opera para el solo efecto de que se dé cumplimiento a una resolución judicial referida a prácticas antisindicales. No se trata, por ende, de una privación de libertad asimilable a la detención ni a una sanción de tipo penal".

${ }^{30}$ El artículo 102 F de la Ley 19.968 dispone lo siguiente: "Si el adolescente no concurriere a la primera citación, el tribunal podrá ordenar que sea conducido a su presencia por medio de la fuerza pública.

En este caso se procurará que la detención se practique en el tiempo más próximo posible al horario de audiencias del tribunal".
} 
Polít. crim. Vol. 13, № 25 (Julio 2018) Art. 10, pp. 350-386.

[http://www.politicacriminal.cl/Vol_13/n_25/Vol13N25A10.pdf]

se le ha hecho por parte del Tribunal de Familia, arresto que tiene el solo objeto de ponerlo a disposición del Juez de Familia". ${ }^{31}$

Por su parte, en la sentencia Rol 2381-12, el TC sostuvo que: “(...) [1]a declaración bajo juramento prevista en el artículo 385 del Código de Procedimiento Civil no puede considerarse una medida de coacción o apremio de aquellas prohibidas por el artículo $19, \mathrm{~N}^{\circ}$ $1^{\circ}$, inciso final, de la Carta Fundamental, sino una solemnidad necesaria para asentar el valor probatorio de la declaración de una parte en el proceso (...)". ${ }^{32}$

Mención especial merecen dos sentencias de este Tribunal. En la primera de ellas (sentencia Rol 2243-12), el TC entendió que la suspensión de funciones prevista en el numeral decimoquinto del Auto Acordado de la Corte Suprema sobre Tramitación y Fallo del Recurso de Protección ${ }^{33}$ constituía un apremio personal, pese a no contemplar una privación de libertad; ${ }^{34}$ mientras que en la segunda, (sentencia Rol 1518-09), el TC desentrañó la verdadera naturaleza jurídica de la privación de libertad que contemplaba el entonces vigente artículo 169 del Código Sanitario calificándola como una pena. A continuación, dada su relevancia, reseñaremos brevemente este último fallo.

La causa Rol 1518-09 corresponde a una acción de inaplicabilidad por inconstitucionalidad interpuesta respecto del artículo 169 del Código Sanitario. ${ }^{35}$ Los requirentes consideraron

31 Tribunal Constitucional, Rol 2743-14, 3 de marzo de 2016, considerando 17. En el mismo sentido, Tribunal Constitucional, Rol 2791-15, 3 de marzo de 2016, considerando 17.

32 Tribunal Constitucional, Rol 2381-12, 20 de agosto de 2013, considerando 25.

${ }^{33}$ La norma en comento establece lo siguiente:

“15. Si la persona, el funcionario o el representante o jefe del órgano del Estado, ya tenga este la calidad de titular, interino, suplente o subrogante, o cualquiera otra, no evacuare los informes o no diere cumplimiento a las diligencias, resoluciones y sentencias dentro de los plazos que la Corte de Apelaciones o la Corte Suprema ordenaren, conforme a lo establecido en este Auto Acordado, podrán estas imponer al renuente, oyéndolo o en su rebeldía alguna o algunas de las siguientes medidas: (...) d) suspensión de funciones hasta por cuatro meses, tiempo durante el cual el funcionario gozará de medio sueldo. Todo ello además de la responsabilidad penal en que pudieran incurrir dichas personas".

${ }^{34}$ El TC estimó que la suspensión de funciones, no se asimilaba a una pena sino a una medida de apremio, establecida con el fin de "ejecutar lo juzgado"; por ende, no resultaba inconstitucional (cons. $24^{\circ}$ ). Sin perjuicio de ello, reconoce que, a partir de la definición literal del concepto de apremio, es difícil apreciar dicho carácter en esta medida, el que se mantiene mientras no se brinde efectivo amparo al derecho amenazado, perturbado o privado que ha motivado la interposición de un recurso de protección (cons. $27^{\circ}$ ).

${ }^{35}$ El texto del artículo 169 del Código Sanitario vigente a la época del requerimiento disponía lo siguiente:

"Si transcurrido el plazo señalado en el artículo anterior, el infractor no hubiere pagado la multa, sufrirá, por vía de sustitución y apremio, un día de prisión por cada décimo de unidad tributaria mensual que comprenda dicha multa.

Para llevar a cabo esta medida, el director del correspondiente servicio de salud o del Instituto de Salud Pública de Chile, en su caso, solicitará del intendente o gobernador respectivo el auxilio de la fuerza pública, quienes dispondrán sin más trámite la detención del infractor y su ingreso al establecimiento penal respectivo, a cuyo efecto librarán la orden correspondiente en conformidad a las reglas generales, dando cuenta de lo obrado a la autoridad sanitaria".

La ley 20.724 (D.O. 14/02/2014) derogó este precepto del Código Sanitario. Las razones que se tuvieron en cuenta para la aprobación de la indicación que propuso su derogación fueron: (i) su carácter discriminatorio, pues -en la práctica- solo las personas de menores ingresos irían a prisión por no pagar la multa; (ii) su infracción a los tratados internacionales que prohíben la prisión por deudas; (iii) la existencia de otro medio para asegurar el cumplimiento de la multa (constitución de un título ejecutivo); (iv) la desproporción de la 
FERNÁNDEZ, José. “Los apremios personales en la jurisprudencia del Tribunal Constitucional: un análisis crítico desde la dogmática de los principios y límites penales”.

que la aplicación de la norma impugnada resultaría contraria al artículo 5 CPR, en relación con el artículo $7.7 \mathrm{CADH}$, y a los números 1 , inc. $3^{\circ}, 4^{\circ}$ y $5^{\circ}$ y 7 , letras a y b, del artículo 19 CPR. Si bien, reconocieron que la institución del arresto como apremio no sería per se inconstitucional, si cumple con las garantías mínimas que consagra la Constitución, sostuvieron que un apremio será ilegítimo, aunque exista la posibilidad de revisión judicial, si es desproporcionado a la consecución de una finalidad lícita y no proviene de una decisión basada en un debido proceso. Además, consideraron que la norma impugnada sería un caso claro e incuestionable de prisión por deudas.

La sentencia citada, de 21 de octubre de 2010, acoge el recurso en atención a los siguientes razonamientos:

En primer lugar, descarta que estemos frente a un caso de prisión por deudas “(...) por cuanto el ilícito castigado con prisión por el mencionado artículo 169 no es el incumplimiento de una deuda, sino la misma infracción sanitaria que motivó la primitiva multa". ${ }^{36}$ No obstante, advierte que estamos ante una situación sin parangón en el derecho chileno por cuanto:

“(...) [E]1 artículo $169,(\ldots)$ convierte automáticamente la multa en pena de prisión, como forma de apremio o presión, habida cuenta de que esta sustitución opera con ejecución administrativa inmediata, cuando aquella no hubiere sido pagada dentro de los cinco días hábiles siguientes a su notificación. Lo señalado contrasta por cierto con otros medios alternativos menos lesivos ideados por el Legislador, para el caso de impago de una multa administrativa, como es dar mérito ejecutivo al acto que la dispone (...)". ${ }^{37}$

En seguida afirma que tanto las sanciones administrativas como las penales son emanaciones del ius puniendi estatal, por lo que debe aplicárseles un estatuto similar que contemple, por ejemplo, el principio de legalidad. Con todo, detecta que según la preceptiva sanitaria objetada y con cobertura simplemente reglamentaria, las sanciones no se imponen a la empresa respectiva, sino que recaen sobre el patrimonio y libertad de sus representantes legales. ${ }^{38}$

Aunque el Código Sanitario permita a la autoridad sanitaria aplicar la pena sin autorización judicial previa, y encontrándose pendiente la sentencia, el TC recuerda que las sanciones impuestas por la Administración no pueden cumplirse mientras no se encuentren ejecutoriadas $^{39}$, ya que materializarlas antes significaría privar de todo efecto práctico una ulterior sentencia favorable. ${ }^{40}$ Siguiendo esta línea argumentativa, el TC señala que las

sanción, que en un hipotético caso podía ocasionar que una persona estuviera más de 20 años en prisión; y, (v) la jurisprudencia del Tribunal Constitucional que declaró inaplicable este precepto en causa Rol 1518-09. Esta (inusual) actuación anticipativa por parte de los legisladores ante una eventual declaración de inconstitucionalidad, refleja una positiva forma de solución al problema que genera la inevitable tensión entre democracia y protección de los derechos en el seno de la jurisdicción constitucional. Para mayor información sobre la tramitación legislativa de esta ley, HISTORIA DE LA LEY 20.724, pp. 272 y 273.

36 Tribunal Constitucional, Rol 1518-09, 21 de octubre de 2010, considerando 4.

37 Tribunal Constitucional, Rol 1518-09, 21 de octubre de 2010, considerando 5.

${ }^{38}$ Tribunal Constitucional, Rol 1518-09, 21 de octubre de 2010, considerando 6.

${ }^{39}$ Tribunal Constitucional, Rol 1518-09, 21 de octubre de 2010, considerando 7.

40 Tribunal Constitucional, Rol 1518-09, 21 de octubre de 2010, considerando 8. 
Polít. crim. Vol. 13, № 25 (Julio 2018) Art. 10, pp. 350-386.

[http://www.politicacriminal.cl/Vol_13/n_25/Vol13N25A10.pdf]

sanciones administrativas también deben sujetarse a las garantías y principios del orden penal establecidos en la Constitución. ${ }^{41}$

En segundo lugar, el TC, a partir de sus anteriores pronunciamientos, reconstruye la verdadera finalidad y naturaleza jurídica de la privación de libertad contemplada en el inciso primero del artículo 169 del Código Sanitario a la hora de determinar la legitimidad de este. Así, sostiene que:

“(...) [N]o puede considerarse de aquellos amparados por el orden constitucional y, por consiguiente, legítimo, toda vez que consiste en una limitación a la libertad que en sí misma no tiene la finalidad propia de un apremio, esto es, compeler a un individuo a realizar una determinada conducta, (...) por lo que en sí misma importa una reacción punitiva ante una conducta del individuo que viene a reemplazar por vía de sustitución el pago de una multa y que, por consiguiente, su finalidad es más bien sancionar al responsable de un acto". 42

El TC, al considerar esta privación de libertad como una pena, establece si esta cumple con los principios y límites penales reconocidos constitucionalmente. La conclusión no puede ser más lapidaria:

“(...) [L]a pena de prisión, utilizada como un apremio, tampoco puede considerarse ajustada a la Constitución, atendido que el precepto reprochado no establece la intervención de la autoridad judicial que decrete la respectiva privación luego de determinar, conforme al mérito de un proceso, la tipicidad de la conducta, su antijuridicidad y la culpabilidad del sujeto. Además, esta carencia de revisión judicial no permite que exista un juzgamiento en torno a si la prisión es necesaria y adecuada como apremio, ni tampoco graduarla de conformidad a la reprochabilidad de la conducta, cuestión que, por lo demás, ni la misma norma lo permite. En efecto, esta al señalar textualmente que se "sufrirá (...) un día de prisión por cada décimo de unidad tributaria mensual", consagra la privación de libertad de modo obligatorio; impide que se utilicen otros medios más adecuados para lograr el cumplimiento de la multa, y que la prisión sea proporcional y graduable de conformidad a las particularidades que asisten al no pago de la multa". ${ }^{43}$

Además, en cuanto a su duración, el apremio impugnado no tendría fijados límites de tiempo, lo que no se condice con el carácter limitado que debe poseer un apremio legítimo. ${ }^{44}$

\subsection{Aplicación del juicio de proporcionalidad.}

Para determinar la legitimidad de un apremio, el TC ha establecido que no basta con examinar la legalidad del mismo; en términos que esté consagrado en la ley, sea decretado por autoridad competente y se lleve a cabo en una cárcel pública, sino que requiere un test

\footnotetext{
${ }^{41}$ Tribunal Constitucional, Rol 1518-09, 21 de octubre de 2010, considerando 8.

42 Tribunal Constitucional, Rol 1518-09, 21 de octubre de 2010, considerando 17.

${ }^{43}$ Tribunal Constitucional, Rol 1518-09, 21 de octubre de 2010, considerando 18.

44 Tribunal Constitucional, Rol 1518-09, 21 de octubre de 2010, considerando 20.
} 
FERNÁNDEZ, José. “Los apremios personales en la jurisprudencia del Tribunal Constitucional: un análisis crítico desde la dogmática de los principios y límites penales".

material de constitucionalidad. ${ }^{45}$ En consecuencia, el TC ha aplicado el juicio de proporcionalidad $^{46}$ para comprobar si la privación o restricción de libertad establecida en los apremios personales protege un fin lícito, es idónea, es necesaria y es proporcional en sentido estricto.

En cuanto a la licitud del fin que persiguen las normas sobre apremios personales, el TC, en la mayoría de sus fallos, ha debido pronunciarse sobre los tratados internacionales que prohíben la prisión por deudas (art. 7.7 Convención Americana de Derechos Humanos, art. 25 Declaración Americana de Derechos Humanos y art. 11 Pacto Internacional de Derechos Civiles y Políticos). El TC ha reconocido la utilidad de estos tratados para determinar la legitimidad de un apremio, ${ }^{47}$ pero, a la vez, ha delimitado el alcance de la proscripción contenida en estas disposiciones, señalando que:

“(...) [L]a prohibición internacional consiste en una limitación al ius puniendi del Estado, en cuanto a no estar este autorizado para criminalizar, esto es, definir o tipificar como delitos y, consecuentemente, aplicar y ejecutar sanciones penales o medidas de naturaleza equivalente privativas de libertad, por el mero incumplimiento de obligaciones civiles contractuales. Por lo mismo, lo que el Estado no puede hacer es considerar delito tal simple incumplimiento contractual. Es decir, no es posible ordenar el aparato punitivo del Estado en función del cumplimiento de obligaciones civiles, en vez de reservar subsidiariamente la reacción penal para la afectación o puesta en peligro de bienes jurídicos esenciales, por medio de ataques especialmente disvaliosos definidos legalmente (...)".48

En efecto, el TC distingue entre obligaciones legales y obligaciones meramente civiles, afirmando que respecto de las primeras no es ilegítimo el apremio dictado por su incumplimiento. Además y como consecuencia de la excepción a la prohibición de prisión por deudas contenida en la $\mathrm{CADH}$, referida al incumplimiento de obligaciones

\footnotetext{
45 Tribunal Constitucional, Rol 2216-12, 22 de enero de 2013, considerando 6. En el mismo sentido, voto de minoría en la sentencia Rol 1006-07, 22 de enero de 2009, considerando 14.

46 Sentencias Rol 519-06 (considerando 19); Rol 1006-07, 22 de enero de 2009 (voto de minoría); Rol 1145 08, 17 de marzo de 2009 (considerando 37); Rol 1518-09, 21 de octubre de 2010 (considerando 14); Rol 197111, 13 de diciembre de 2011 (considerando 8); Rol 2102-11, 27 de septiembre de 2012 (considerando 42); Rol 2216-12, 22 de enero de 2013 (considerando 8); Rol 2265-12, 21 de noviembre de 2013 (considerando 15); Rol 2743-14, 3 de marzo de 2016 (considerando 18); y, Rol 2791-15, 3 de marzo de 2016 (considerando 18).

${ }^{47}$ Prevención de los ministros Vodanovic, Fernández y Correa en la sentencia Rol 1006-07, de 22 de enero de 2009, quienes señalaron: "A nuestro juicio, para dar un significado al concepto de legitimidad de un apremio y determinar los límites razonablemente justificados de la libertad personal (...), resulta pertinente, en este caso, remitirse al derecho internacional de los derechos humanos (...)". En contra se pronuncia la sentencia Rol 226512, de 21 de noviembre de 2013, en cuyo considerando $8^{\circ}$, el TC sostuvo: "Que, como lo ha sustentado uniformemente esta judicatura constitucional, los tratados internacionales no constituyen, per se, parámetros autónomos de control de constitucionalidad, en el sentido de habilitar directamente a esta jurisdicción para contrastar su sentido y alcance con los preceptos legales que presuntamente los contrarían. Para que esta operación fuera jurídicamente válida, sería necesario que aquellos instrumentos estuvieren dotados de rango constitucional en cuanto fuentes formales de Derecho Constitucional, y no adquirirla por vía simplemente indirecta, a través de la remisión que a ellos formula el inciso segundo del artículo 5 de la Carta Fundamental". ${ }^{48}$ Tribunal Constitucional, Rol 2102-11, 27 de septiembre de 2012, considerando 30. Un análisis más acucioso se realiza en la sentencia Rol 807-07, de 4 de octubre de 2007, en los considerandos 12 al 14.
} 
Polít. crim. Vol. 13, No 25 (Julio 2018) Art. 10, pp. 350-386.

[http://www.politicacriminal.c1/Vol_13/n_25/Vol13N25A10.pdf]

previsionales $^{49}$ y de pago de la compensación económica ${ }^{50}$-excepción fundamentada en razón del carácter asistencial que atribuye a ambas obligaciones ${ }^{51}$ el TC ha ampliado el abanico de los apremios que persiguen un fin legítimo. Por tanto, diferencia entre meras obligaciones civiles y obligaciones civiles con un "especial interés social" en las que resulta legítimo la imposición de un apremio personal.

De este modo, la licitud del fin se configuraría en el interés público comprometido en el cumplimiento de ciertas obligaciones. Así, en relación al deber legal del empleador de enterar los dineros correspondientes a las cotizaciones de seguridad social, el TC ha señalado que “(...) corresponde a un apremio con un claro interés social y público involucrado, toda vez que del pago de las respectivas cotizaciones pende en buena medida un correcto funcionamiento del sistema de seguridad social (...)". ${ }^{52}$ Idénticas consideraciones ha tenido el TC respecto de los apremios decretados en el ámbito tributario ${ }^{53}$ y para el caso de incumplimiento del pago de la compensación económica. ${ }^{54}$

Un planteamiento interesante encontramos en la sentencia Rol 1145-08, en la que se incluyen otros intereses como fines legítimos. Es así como el TC advierte que el artículo 32 de la Ley 18.695, en relación con el Art. 238 CPC, no consagra “(...) un apremio ilegítimo de aquellos que se encuentran prohibidos por la Carta Fundamental sino que (...) instituye una forma o modalidad de ejecución de una sentencia judicial, en cumplimiento de los estatuidos (sic) por el artículo 76 de la misma Constitución, de modo que no solo se favorece el interés social sino que el funcionamiento mismo del Estado de Derecho". 55

Es más, en dicho fallo, los ministros Raúl Bertelsen y Jorge Correa reconocen que el cumplimiento de una sentencia judicial que condena a un Municipio al pago de una deuda originada en un contrato de arrendamiento es un fin lícito, que tiene reconocimiento constitucional. ${ }^{56}$

\footnotetext{
49 Tribunal Constitucional, sentencias Rol 576-06 (considerando 29) y Rol 519-06 (considerando 29).

50 Tribunal Constitucional, Rol 2102-11, 27 de septiembre de 2012, considerandos 15 y 16.

${ }^{51}$ Así, respecto a la obligación previsional el TC ha manifestado que “(...) la similitud es evidente si se tiene presente que tanto los alimentos como la obligación de pago de pensiones tienen fuente legal, pretenden atender estados de necesidad de las personas, propenden a la manutención de quien los recibe, se encuentran establecidos a favor del más débil y, por último, ambos envuelven un interés social y, consecuencialmente, están regulados por normas de orden público”. Tribunal Constitucional, Rol 519-06, 5 de junio de 2007, considerando 31. En relación a la compensación económica, a pesar de identificar algunas diferencias entre esta obligación y la obligación previsional, el TC reconoce que “(...) si bien la compensación económica no tiene una exclusiva naturaleza alimentaria, exhibe sin embargo múltiples características y elementos de los alimentos $\mathrm{y}$, en todo caso, una naturaleza asistencial para ciertos efectos (...)". Tribunal Constitucional, Rol 2102-11, 27 de septiembre de 2012, considerandos 15 y 16.

52 Tribunal Constitucional, Rol 576-07, 24 de abril de 2007, considerando 29. En el mismo sentido, Tribunal Constitucional, Rol 519-06, 5 de junio de 2007, considerando 27.

53 Tribunal Constitucional, Rol 1006-07, 22 de enero de 2009, considerando 29 (voto de mayoría). En el mismo sentido, Tribunal Constitucional, Rol 2216-12, 22 de enero de 2013 (voto disidente).

${ }^{54}$ Tribunal Constitucional, Rol 2102-11, 27 de septiembre de 2012, considerando 43.

55 Tribunal Constitucional, Rol 1145-08, 17 de marzo de 2009, considerando 34.

56 Tribunal Constitucional, Rol 1145-08, 17 de marzo de 2009, considerando 14 (prevención de los ministros Bertelsen y Correa).
} 
FERNÁNDEZ, José. “Los apremios personales en la jurisprudencia del Tribunal Constitucional: un análisis crítico desde la dogmática de los principios y límites penales”.

Respecto a la idoneidad, El TC ha estimado que el apremio de arresto resulta una medida idónea para la consecución de los fines que persigue. Por ejemplo, respecto a las obligaciones tributarias ha mantenido que "(...) la medida de apremio dispuesta en este caso es perfectamente proporcional y no ha devenido inconstitucional, toda vez que persigue un fin legítimo por medios mínimamente invasivos, considerando la importancia de los intereses públicos involucrados en la satisfacción de las obligaciones tributarias ${ }^{57 \%}$. En esa misma línea el TC, en la sentencia Rol 2102-11, mantiene que “(...) la medida de apremio de arresto nocturno satisface el baremo internacional y constitucional. Y es, en todo caso, más benigna que la consideración propiamente penal de la eventual configuración de un delito de quebrantamiento de sentencia, en los términos del artículo 240 del Código de Procedimiento Civil, que en este caso resulta desplazada". ${ }^{8}$

No obstante, algunos ministros han cuestionado la idoneidad del apremio de arresto, evidenciando que "(...) un arresto hasta por 15 días, renovable, es, a no dudarlo, una restricción severa a la libertad personal. La persona sometida a un arresto ve impedido su derecho a residir y a permanecer en el lugar de su elección y a trasladarse en el territorio de la República. Su libertad queda sometida al confinamiento carcelario y a sus severas reglas". 59

El carácter necesario de estas medidas ha sido objeto de mayores reparos. Así, por una parte, aplicando el principio de mínima intervención, diversas sentencias han puesto de relieve que el arresto deber ser adoptado como una medida extrema y excepcional; ${ }^{60} \mathrm{y}$, por otra, se ha planteado que existen otros medios menos restrictivos para obtener el cumplimiento de obligaciones. De esta manera, el TC, a partir de un examen concreto de constitucionalidad, ha determinado si existen medios equivalentes, por lo menos, de una misma idoneidad a la de la medida para contribuir a alcanzar el fin constitucionalmente legítimo desde todas las perspectivas posibles (eficacia, temporalidad, probabilidad del fin, entre otras), y, a la vez, estos limiten en menor medida los derechos fundamentales comprometidos por la medida. ${ }^{61}$ Así, en el voto de minoría de la sentencia Rol 1145-08, referida al apremio recaído sobre un alcalde, los ministros Bertelsen y Correa establecieron por primera vez una línea argumental sobre la necesidad de los apremios personales. Así, manifestaron:

“(...) [N]o puede estimarse como legítimo el apremio consistente en hasta dos meses de arresto renovables que pueda decretar un juez en contra de un alcalde con el único objeto de presionar por el cumplimiento de una sentencia civil de pago de una deuda patrimonial del respectivo municipio, pues existen otros medios menos restrictivos de una libertad fundamental, como es la personal, para obtener el cumplimiento de

\footnotetext{
57 Tribunal Constitucional, Rol 2216-12, 22 de enero de 2013, (voto disidente).

58 Tribunal Constitucional, Rol 2102-11, 27 de septiembre de 2012, considerando 38.

${ }^{59}$ Voto de minoría en la Sentencia Rol 1006-07, 22 de enero de 2009, considerando 12.

60 Tribunal Constitucional, Rol 576-06, 24 de abril de 2007, considerando 37. En el mismo sentido, las sentencias Rol 1518-09 (considerando 32) y Rol 1006-07 (considerando 37, voto de mayoría).

${ }^{61}$ Por todos, BERNAL, Carlos, El principio de proporcionalidad y derechos fundamentales, Madrid: Centro de Estudios Constitucionales, 2005, p. 748.
} 
Polít. crim. Vol. 13, № 25 (Julio 2018) Art. 10, pp. 350-386.

[http://www.politicacriminal.c1/Vol_13/n_25/Vol13N25A10.pdf]

obligaciones establecidas en una sentencia judicial originadas en un contrato de arrendamiento". 62

Siguiendo una línea argumental similar, el TC, en la sentencia Rol 2216-12, reconoce que existen otros medios idóneos menos gravosos de la libertad personal para obtener el cumplimiento de obligaciones tributarias, como el ejercicio del derecho de prenda general que corresponde a todo acreedor. ${ }^{63}$ Asimismo, en la sentencia Rol 1518-09, el TC concluye que la aplicación del artículo 169 del Código Sanitario no sería el único y necesario medio para proteger la vida y la salud de la población, toda vez que la autoridad sanitaria podría denunciar a la justicia los delitos contra la salud pública que eventualmente pueda detectar en el ejercicio de sus funciones. ${ }^{64}$

No obstante, tenemos jurisprudencia que se decanta por una suerte de control abstracto sobre la necesidad de la medida. La sentencia Rol 2102-11, si bien no declara inaplicable el precepto impugnado (artículo 14 de la Ley 14.908), igualmente sostiene que el apremio de arresto restringe la libertad del afectado “(...) en la medida estrictamente necesaria, ya que cesará tan pronto se cumpla la obligación o, incluso, (...) cesará si el deudor hubiere ofrecido otras garantías para su efectivo y oportuno pago (...)".65

Sobre la proporcionalidad en sentido estricto del apremio de arresto ha habido distintas visiones. En la mayoría de los casos se ha considerado proporcional el arresto, eso sí, teniendo presente diversas razones. Así, algunos fallos aluden al carácter breve de la restricción de la libertad personal. Por ejemplo, en la sentencia Rol 1971-11 el TC sostuvo que las normas que consagran un apremio destinado a asegurar el cumplimiento de una resolución judicial, “(...) implican una restricción a la libertad personal muy limitada en el tiempo. El arresto solo puede extenderse por dos meses, renovables, el cual puede ser evitado por el requirente en la medida que dé cumplimiento al reintegro ordenado por la sentencia". ${ }^{6}$

\footnotetext{
${ }^{62}$ Prevención de los ministros Bertelsen y Correa en sentencia Rol 1145-08, 17 de marzo de 2009, considerando 13. En el mismo sentido, voto de minoría en la sentencia Rol 1006-07, 22 de enero de 2009, considerando 17; y, Tribunal Constitucional, Rol 2216-12, 22 de enero de 2013, considerando 8.

${ }^{63}$ Tribunal Constitucional, Rol 2216-12, 22 de enero de 2013, considerando 8. En el mismo sentido se pronuncia el voto de minoría de los ministros señores Hernán Vodanovic, Mario Fernández y Jorge Correa en la sentencia Rol 1006-07, de 22 de enero de 2009. Estos ministros consideraron que la severa limitación de la libertad personal que permitía el precepto impugnado (artículo 96 del Código Tributario) carecía de proporcionalidad. Si bien, estimaron que el fin perseguido por la norma objetada -recolectar tributos- era lícito y tenía reconocimiento constitucional, y que a su vez el apremio sería un medio "idóneo" y "eficaz" para la consecución de este fin, igualmente consideraron que la medida de privación de libertad de 15 días de arresto renovables e inapelables, que debe decretarse con el solo mérito de una audiencia, no era un medio proporcional al objetivo de obtener una adecuada recaudación tributaria, toda vez que "(...) existen muchos otros medios al alcance del derecho para obtener el pago de una deuda; entre ellos, el más importante, el de prenda general que corresponde a todo acreedor y, desde luego, al Fisco como acreedor tributario, para hacerse pago con todos los bienes del deudor".

${ }^{64}$ Tribunal Constitucional, Rol 1518-09, 21 de octubre de 2010, considerando 32.

65 Tribunal Constitucional, Rol 2102-11, 27 de septiembre de 2012, considerando 43.

66 Tribunal Constitucional, Rol 1971-11, 13 de diciembre de 2011, considerando 11. En el mismo sentido, Sentencias del Tribunal Constitucional, Rol 2743-14, 3 de marzo de 2016, considerando 19 y, Rol 2791-15, 3 de marzo de 2016, considerando 19.
} 
FERNÁNDEZ, José. “Los apremios personales en la jurisprudencia del Tribunal Constitucional: un análisis crítico desde la dogmática de los principios y límites penales".

Este argumento es complementado con la alusión a la no afectación del contenido esencial del derecho a la libertad personal y seguridad individual que se hace en la sentencia Rol 2265$12 .^{67}$

A su vez, en la sentencia Rol 2102-11, el TC ha estimado que un apremio resulta proporcionado, si con ello se evita la afectación de otro derecho fundamental. En dicho fallo, el TC mantiene:

"Que, por consiguiente, el no cumplimiento injustificado de las obligaciones de familia en materia de compensación económica con respecto a la mujer divorciada, importa de suyo y por sí mismo una forma de discriminación omisiva inaceptable, de modo que se dispone la medida de apremio de arresto para corregirla. Mediante esa medida de última ratio, se tiende a crear de facto igualdad de oportunidades entre los ex cónyuges y a no perpetuar diferencias arbitrarias entre ambos, en armonía con el artículo $1^{\circ}$, inciso final, y artículo $19, \mathrm{~N}^{\circ} 2^{\circ}$, de la Constitución Política. Por consiguiente, este Tribunal Constitucional considera justificada o proporcionada la medida de apremio dispuesta, por lo que la aplicación legal de la misma no vulnera el derecho a la libertad personal y seguridad individual, razón por la cual será también rechazado este segundo capítulo de inconstitucionalidad". ${ }^{6}$

No obstante, es posible constatar fallos en que se ha descartado la estricta proporcionalidad del apremio de arresto sobre la base de distintas consideraciones. Así, en la causa Rol 114508 el TC sostuvo que:

“(...) [E]l apremio dispuesto contra el Alcalde de Arauco (...) siendo legítimo en su origen, ha devenido en ilegítimo, pues no aparece, en la actualidad, proporcionado a la consecución de un fin de interés social relacionado con la decisión de autoridad competente, en el marco de un proceso justo, en la medida que se mantiene vigente más allá del supuesto previsto en las normas legales tenidas en vista para decretarlo". ${ }^{69}$

En cambio, en la sentencia Rol 1518-09, el TC mantiene que el arresto no es proporcional porque " (...) permite consolidar irremediablemente una pena privativa de libertad, hasta por hechos (...) de ínfima magnitud y en los que puede no haber mediado ni siquiera culpa del infractor". 70

\footnotetext{
${ }^{67}$ Tribunal Constitucional, Rol 2265-12, 21 de noviembre de 2013, considerando 15: "Que la medida de arresto nocturno prevista en el artículo 14, inciso primero, de la Ley $\mathrm{N}^{\circ} 14.908$ no es, en definitiva, una medida privativa, sino restrictiva de la libertad personal, mínimamente invasiva, que no produce el efecto paradojal de impedir el trabajo del deudor para pagar su obligación, como ocurriría en el caso de tratarse de un arbitrio privativo de la libertad. No es, por ende, una limitación desproporcionada, susceptible de comprometer ese derecho fundamental en su esencia, lo que excluye su calificación como un apremio ilegítimo, como, por lo demás, lo declaró este Tribunal en su pronunciamiento recaído en el Rol N²102, de 27 de septiembre de 2012”. ${ }^{68}$ Tribunal Constitucional, Rol 2102-11, 27 de septiembre de 2012, considerando 45.

${ }^{69}$ Tribunal Constitucional, Rol 1145-08, 17 de marzo de 2009, considerando 37. Con todo, conviene precisar que nos encontramos frente a un caso de ilegalidad y no frente a uno de desproporción en sentido estricto, ya que el alcalde afectado por el apremio ya había dictado el correspondiente decreto alcaldicio que ordenaba el pago de la deuda municipal, por lo que no se verificaba el supuesto de hecho previsto en el artículo 32 de la Ley 18.695 .

${ }^{70}$ Tribunal Constitucional, Rol 1518-09, 21 de octubre de 2010, considerando 29.
} 
Polít. crim. Vol. 13, № 25 (Julio 2018) Art. 10, pp. 350-386.

[http://www.politicacriminal.c1/Vol_13/n_25/Vol13N25A10.pdf]

Por último, en la sentencia Rol 1006-07, los ministros Vodanovic, Fernández y Correa plantearon que, a partir del reconocimiento constitucional tanto de la libertad personal y la Hacienda pública, entendieron que "no parece necesario ni proporcional que se emplee un medio tan gravoso a la primera para alcanzar la segunda". ${ }^{71}$

\subsection{Otras garantías constitucionales.}

En este apartado analizaremos la aplicación de otros límites al ius puniendi aplicados en el control de constitucionalidad de los apremios personales.

En cuanto al principio de culpabilidad, el TC ha detectado infracciones a la presunción de inocencia y a la prohibición de presumir de derecho la responsabilidad penal (artículo 19, número 3, inciso séptimo CPR), por ejemplo, en los casos en que se aplican apremios sin que esté firme o ejecutoriada la resolución que lo dispone y, por tanto, no se encuentra acreditada la responsabilidad del afectado. ${ }^{72}$

No obstante, en la sentencia Rol 519-06, el TC rechaza la alegación de los requirentes quienes sostuvieron que el inciso segundo del artículo 3 de la Ley $17.322^{73}$ consagraba una presunción de derecho que permitía, sin un proceso legalmente tramitado, que se despachen órdenes de arresto, en virtud de lo dispuesto en el inciso primero del artículo 12 de la misma Ley, mediante resoluciones que constituirían una verdadera sentencia condenatoria. En su sentencia el TC afirma que el referido precepto no establece una presunción de derecho de responsabilidad penal que transgreda la Constitución. Tomando como referencia la historia del establecimiento del artículo 19 , número 3, inciso sexto $\mathrm{CPR}^{74} \mathrm{y}$ los planteamientos de la

71 Tribunal Constitucional, Rol 1006-07, 22 de enero de 2009 (prevención de los ministros Vodanovic, Fernández y Correa). En el mismo sentido, la sentencia Rol 2216-12, 22 de enero de 2013, en cuyo considerando $8^{\circ}$ el TC considera que la aplicación del artículo 93 del Código Tributario “(...) constituye una severa limitación de la libertad personal que carece de proporcionalidad".

${ }^{72}$ De este modo el TC sostuvo que el artículo 169 del Código Sanitario, vulneraba el principio de culpabilidad (artículo 19, № 3, inciso sexto CPR), en específico a la presunción de inocencia, ya que “(...) permite anticipar la ejecución administrativa de una pena de prisión, antes de encontrarse firme dicha sanción, mientras los hechos que dan por establecida la infracción y por acreditada la responsabilidad se encuentran discutidos en sede judicial. De suerte que, aunque el reclamo judicial prospere, la eventual sentencia favorable podría devenir enteramente inocua o carente de significación real, al haberse consumado antes y producido todos sus efectos irreversibles esa pena de prisión". Tribunal Constitucional, Rol 1518-09, 21 de octubre de 2010, considerando 36. En el mismo sentido, prevención de los ministros Vodanovic, Fernández y Correa en sentencia Rol 100607, de 22 de enero de 2009, quienes señalaron que el apremio contenido en el artículo 96 del Código Tributario no podría considerarse legítimo en razón de que pudiéramos estar frente a un acto ilícito de quien retiene y no entera el impuesto. El Estado solo podría reaccionar legítimamente a través de un debido proceso en que se acredite la conducta típica, antijurídica y culpable. Por lo tanto, el apremio no sería una reacción estatal legítima de privación de libertad pues se anticiparía al juicio penal bajo la presunción de que ha habido un ilícito. Este voto de minoría sirvió de base para la posterior declaración de inaplicabilidad de los artículos 93 y 96 del Código Tributario en la sentencia Rol 2216-12, de 22 de enero de 2013, en cuyo considerando 10 el TC precisó que "[1]a participación culpable en un ilícito debe ser establecida y acreditada previamente en un debido proceso, sin desmentir el estado de inocencia ni la prohibición de presumir de derecho la responsabilidad criminal".

${ }^{73} \mathrm{El}$ artículo $3^{\circ}$ inciso segundo de la Ley 17. 322 dispone: "[s] e presumirá de derecho que se han efectuado los descuentos a que se refiere ese mismo artículo [ $2^{\circ}$ de la misma Ley], por el solo hecho de haberse pagado total o parcialmente las respectivas remuneraciones a los trabajadores. Si se hubiere omitido practicar dichos descuentos, será de cargo del empleador el pago de las sumas que por tal concepto se adeuden".

74 Tribunal Constitucional, Rol 519-06, 5 de junio de 2007, considerando 40. 
FERNÁNDEZ, José. “Los apremios personales en la jurisprudencia del Tribunal Constitucional: un análisis crítico desde la dogmática de los principios y límites penales".

doctrina sobre su significado ${ }^{75}$, el TC considera que el artículo 3 contiene una presunción de derecho respecto al hecho de haberse efectuado el descuento de la remuneración de los dineros correspondientes a las cotizaciones de seguridad social. ${ }^{76}$ A ello agrega que esta presunción debe distinguirse del delito de apropiación indebida de cotizaciones previsionales tipificado en el artículo 13 de la Ley 17.322, figura penal que, en opinión del TC, cumple con todos los requisitos y presupuestos de un delito, ya que describe la conducta típica, antijurídica y culpable que sanciona. ${ }^{77}$ El artículo 3 de la citada ley no presumiría la concurrencia de estos elementos, sino únicamente una conducta (efectuar los descuentos de cotizaciones previsionales) que posterior $\mathrm{y}$, eventualmente, podría dar lugar a una responsabilidad penal, si es que concurren el resto de los presupuestos del delito como, por ejemplo, el ánimo de apropiación. ${ }^{78}$

Estrechamente vinculado al principio de culpabilidad, se encuentra el pronunciamiento que ha tenido el TC respecto al derecho a un debido proceso. En este punto, el debate se ha centrado principalmente en el contenido de este derecho, es decir, en las garantías que este comprende.

El TC ha concretado, a partir del artículo 19, número 7 CPR, las siguientes garantías:

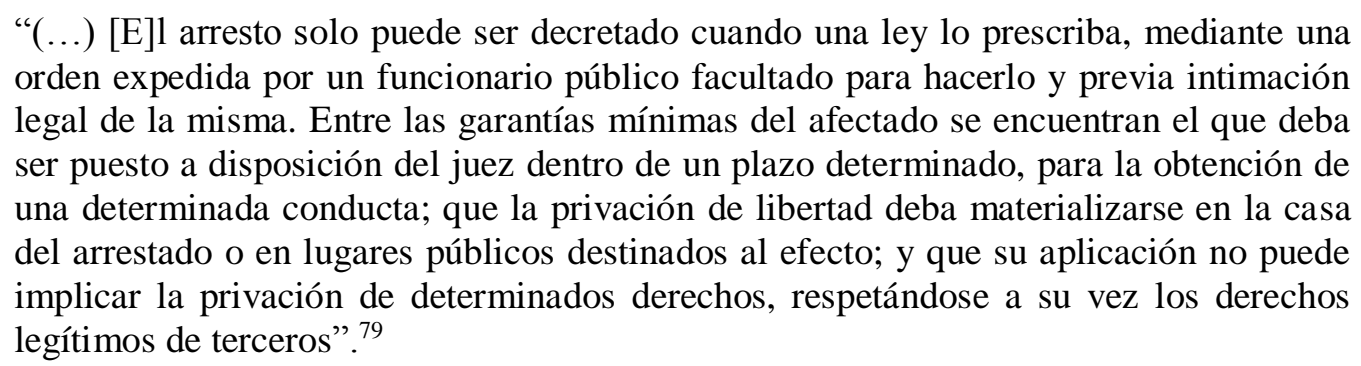

En la mayoría de sus fallos, el TC ha considerado que estas garantías se cumplen. El caso más claro en que el TC ha detectado infracciones al debido proceso es el resuelto en la sentencia Rol 1518-09. El TC adujo, como unas de las razones para estimar la inaplicabilidad del derogado inciso segundo del artículo 169 del Código Sanitario, la facultad con que contaba la autoridad administrativa para disponer, sin intervención judicial, la detención e ingreso a un recinto penal del sujeto que no haya pagado la multa impuesta en un sumario sanitario. ${ }^{80}$

El TC, indaga sobre el alcance del inciso sexto del artículo 19, número 3, CPR, señalando que de la historia fidedigna del establecimiento del precepto se desprende que:

\footnotetext{
75 Tribunal Constitucional, Rol 519-06, 5 de junio de 2007, considerando 41.

76 Tribunal Constitucional, Rol 519-06, 5 de junio de 2007, considerando 44.

77 Tribunal Constitucional, Rol 519-06, 5 de junio de 2007, considerando 47.

78 Tribunal Constitucional, Rol 519-06, 5 de junio de 2007, considerando 48.

79 Tribunal Constitucional, Rol 576-06, 24 de abril de 2007, considerando 18. En el mismo sentido, sentencias Rol 1006-07, 22 de enero de 2009 (considerando 20, voto de mayoría); Rol 519-06, 5 de junio de 2007 (considerando 18); y, Rol 1518-09, 21 de octubre de 2010 (considerando 12).

${ }^{80}$ Tribunal Constitucional, Rol 1518-09, 21 de octubre de 2010, considerando 21.
} 
Polít. crim. Vol. 13, No 25 (Julio 2018) Art. 10, pp. 350-386.

[http://www.politicacriminal.c1/Vol_13/n_25/Vol13N25A10.pdf]

“(...) [S]e estimó conveniente otorgar un mandato al legislador para establecer siempre las garantías de un proceso racional y justo, en lugar de señalar con precisión en el propio texto constitucional cuáles serían los presupuestos mínimos del debido proceso, sin perjuicio de dejar constancia que algunos de dichos elementos decían relación con el oportuno conocimiento de la acción y debido emplazamiento, bilateralidad de la audiencia, aportación de pruebas pertinentes y derecho a impugnar lo resuelto por un tribunal, imparcial e idóneo y establecido con anterioridad por el legislador". ${ }^{81}$

El TC hace alusión a su doctrina sobre la aplicación de las garantías del debido proceso al derecho administrativo, aunque con matices relativos a las características propias de esta rama del derecho. En el caso concreto, considera:

"Que la disposición que se analiza [el artículo 169 del Código Sanitario] también infringe el debido proceso, toda vez que (...), por una parte, se está en presencia de una pena que, aunque dispuesta como apremio, supone la privación de libertad, sin que exista un proceso jurisdiccional en el que tenga lugar el principio de bilateralidad de la audiencia ante un tercero imparcial y, por consiguiente, en que se haya respetado el derecho de defensa de quien será objeto de una limitación a su libertad. Y, por otra parte, esta clase de coactividad estatal exige que la respuesta del Estado emane de una sentencia judicial que cause ejecutoria, dictada de conformidad al mérito de un justo y racional procedimiento, debidamente tramitado, tal como exige perentoriamente el artículo 19, $\mathrm{N}^{\circ} 3$, inciso quinto de la Constitución Política de la República". ${ }^{2}$

Es más, el TC estima que, además, la aplicación efectiva del artículo 169 del Código Sanitario “(...) supone impedir el acceso a la justicia, toda vez que el pago de la multa, al no consistir ahora en un requisito para poder reclamar de ella, importa reconocer como verdadera una actuación infraccional y aceptar una sanción solo con la finalidad de no ser sometido a prisión". ${ }^{83}$

También el TC ha acudido a la interpretación conforme con la Constitución a la hora de compatibilizar el contenido de un apremio personal con las garantías del debido proceso. En la sentencia Rol 2438-13, el TC realiza una interpretación restrictiva del artículo 32 de la Ley 18.695 Orgánica Constitucional de Municipalidades para así cautelar el respeto al derecho al debido proceso. De este modo afirma que:

“(...) [L]a única hermenéutica que se conforma con el espíritu de la Ley Fundamental es la que reduce la opción de apremio a solo la máxima autoridad comunal vinculada a la deuda, en razón de haber sido contraída en su ejercicio. Adversativamente, la ampliación de su alcance, en términos de extender la medida de arresto a cualquier ex alcalde, en cualquier tiempo, importaría un atentado a la regla del debido proceso, puesto que se facultaría a los jueces para privar de libertad a quien no ha adquirido obligación personal alguna, pues la deuda es anterior a su gestión. Más grave aún, no podría liberarse de su carga personal, susceptible de repetirse indefinidamente en el tiempo,

\footnotetext{
${ }^{81}$ Tribunal Constitucional, Rol 1518-09, 21 de octubre de 2010, considerando 23.

82 Tribunal Constitucional, Rol 1518-09, 21 de octubre de 2010, considerando 25.

${ }^{83}$ Tribunal Constitucional, Rol 1518-09, 21 de octubre de 2010, considerando 26.
} 
FERNÁNDEZ, José. “Los apremios personales en la jurisprudencia del Tribunal Constitucional: un análisis crítico desde la dogmática de los principios y límites penales”.

sino pagando con sus propios bienes, con la consiguiente afectación de su propio patrimonio $(\ldots) " .84$

En otro fallo estimatorio de inaplicabilidad, sentencia Rol 2216-12, el TC detectó una transgresión a la garantía relativa a la igual protección de la ley en el ejercicio de los derechos, por cuanto " (...) se restringe la libertad personal a través de una sanción que no ha sido precedida de un proceso previo seguido conforme a un procedimiento racional y justo" 85 , máxime si el arresto se decreta por medio de una resolución inapelable, renovable indefinidamente y sin fase probatoria alguna.

No obstante, el TC ha limitado el alcance de las garantías comprendidas en el artículo 19, número 7 CPR. Así, podemos destacar tres fallos del TC. En el primero, sentencia Rol 57607, el TC, resolvió un requerimiento presentado por Francisco Petour Goycolea respecto de los artículos 12 y 14 de la Ley $17.322 .{ }^{86}$ El requirente consideró que la aplicación de estos preceptos legales, resultaría contraria al artículo $5 \mathrm{CPR}$ en cuanto estos preceptos consagrarían una prisión por deudas, proscrita por derechos esenciales que emanan del artículo 7.7 CADH y el artículo 11 del Pacto Internacional de Derechos Civiles y Políticos (en adelante PIDCP); al artículo 19 número $3 \mathrm{CPR}$, pues el carácter inapelable de las resoluciones que decretan el apremio le privaría de protección judicial; y, al artículo 19, número 7 CPR, ya que la privación de libertad a título de apremio, contravendría el derecho a la libertad personal.

\footnotetext{
${ }^{84}$ Tribunal Constitucional, Rol 2438-13, 10 de abril de 2014, considerando 31.

${ }^{85}$ Tribunal Constitucional, Rol 2216-12, 22 de enero de 2013, considerando 11.

${ }^{86}$ Los preceptos impugnados disponen:

“Artículo 12. -El empleador que no consignare las sumas descontadas o que debió descontar de la remuneración de sus trabajadores y sus reajustes e intereses penales, dentro del término de quince días, contado desde la fecha del requerimiento de pago si no opuso excepciones, o desde la fecha de la notificación de la sentencia de primera instancia que niegue lugar a ellas, será apremiado con arresto, hasta por quince días. Este apremio podrá repetirse hasta obtener el pago de las sumas retenidas o que han debido retenerse y de sus reajustes e intereses penales.

El apremio será decretado, a petición de parte, por el mismo tribunal que esté conociendo de la ejecución y con el solo mérito del certificado del secretario que acredite el vencimiento del término correspondiente y el hecho de no haberse efectuado la consignación.

Las resoluciones que decreten estos apremios serán inapelables.

La consignación de las cantidades adeudadas hará cesar el apremio que se hubiere decretado en contra del ejecutado, pero no suspenderá el curso del juicio ejecutivo, el que continuará tramitándose hasta que se obtenga el pago del resto de las sumas adeudadas.

Las instituciones de previsión, en los casos contemplados en este artículo, deberán recibir el pago de las cantidades descontadas o que debieron descontarse y de sus reajustes e intereses penales, aun cuando no se haga el del resto de las adeudadas.

Para los efectos contemplados en este artículo, la liquidación que debe hacer el secretario del tribunal con arreglo a lo establecido en el artículo $7^{\circ}$ señalará expresa y determinadamente las cotizaciones y aportes legales que se descontaron o debieron descontarse de las remuneraciones de los trabajadores.

Tanto la orden de apremio como su suspensión, deberán ser comunicadas a la Policía de Investigaciones de Chile, para su registro".

"Artículo 14. En caso que el empleador sea una persona jurídica de derecho privado o público, una comunidad, sociedad o asociación de hecho, el apremio a que se refiere el artículo 12 se hará efectivo sobre las personas señaladas en el artículo 18”.
} 
Polít. crim. Vol. 13, № 25 (Julio 2018) Art. 10, pp. 350-386.

[http://www.politicacriminal.cl/Vol_13/n_25/Vol13N25A10.pdf]

En su sentencia, el TC, a pesar de tener presente sus pronunciamientos sobre el alcance de este derecho ${ }^{87}$ y los planteamientos de la doctrina, especialmente de autores como José Luis Cea y Enrique Evans que incluyen la revisión judicial por un tribunal superior dentro de las garantías de un racional y justo procedimiento, ${ }^{88}$ termina inclinándose por lo planteado por Juan Colombo en orden a que "(...) todo proceso debido debe contener un sistema que los contemple [los recursos procesales], salvo en aquellos casos en que, por la naturaleza del conflicto, sea recomendable que el tribunal ejerza su jurisdicción en única instancia". ${ }^{89}$ En consecuencia, el TC consideró que la eventual aplicación de apremios no contravendría disposiciones constitucionales, pues sería dictada "en el contexto de un proceso que reúne todas las exigencias de un debido proceso". 90 Además, señaló que si la resolución que impusiera un arresto fuera infundada, ilegal o arbitraria, podría ser impugnada a través del Recurso de Amparo (artículo $21 \mathrm{CPR}) .{ }^{91}$

En el segundo fallo, causa Rol 2381-12, el TC resuelve un requerimiento de inaplicabilidad por inconstitucionalidad presentado por Ismael Correa por sí y como representante legal de Empresas Ariztía S.A., ${ }^{92}$ respecto del artículo 29 del Decreto Ley 211 de 1973, sobre Defensa de la Libre Competencia, que, entre otras normas, permite la aplicación del inciso primero del artículo 385 CPC en una gestión judicial pendiente ante el Tribunal de Defensa de la Libre Competencia. ${ }^{93}$ El requirente expresó que -en su calidad de representante legal -se le citó a absolver posiciones bajo juramento, pudiéndosele aplicar los apercibimientos del artículo 394 CPC, esto es, multa, arresto y, si no comparece en segunda citación, el de tenerlo por confeso respecto de los hechos categóricamente afirmados en el pliego de posiciones. Entre otras disposiciones constitucionales, el requirente estimó infringido el artículo 19, número 7 letra f CPR, por cuanto la gestión judicial pendiente sería una causa criminal de derecho administrativo sancionador, a la que se le extienden las garantías procesales penales, entre ellas, la garantía de la no autoincriminación. La aplicación de las normas impugnadas, afectaría en su esencia su derecho a la libertad personal y seguridad individual (artículo 19, número $26 \mathrm{CPR})$.

En su sentencia, de fecha 20 de agosto de 2013, el TC mantuvo que la prohibición de autoincriminación no es una garantía general de todo procedimiento, sino que solo beneficia a quien encuentra amenazada su libertad personal o seguridad individual en el curso de una

\footnotetext{
${ }^{87}$ Tribunal Constitucional, Rol 576-07, 24 de abril de 2007, considerando 42.

88 Tribunal Constitucional, Rol 576-07, 24 de abril de 2007, considerando 43.

${ }^{89}$ Tribunal Constitucional, Rol 576-07, 24 de abril de 2007, considerando 43. Colombo. J., El debido proceso constitucional, trabajo preparado para el encuentro anual de la Corte Constitucional Italiana, Roma, diciembre, 2003, p. 108. Disponible en: http://www.tribunalconstitucional.cl/wp/descargar_documento.php?id=589.

90 Tribunal Constitucional, Rol 576-07, 24 de abril de 2007, considerando 45.

91 Tribunal Constitucional, Rol 576-07, 24 de abril de 2007, considerando 44.

92 El TC declaró admisible el requerimiento solo respecto de Empresas Ariztía S.A., pues consideró que su representante legal, en tanto persona natural, no era parte en la gestión judicial pendiente.

${ }^{93}$ Los preceptos legales impugnados disponen: artículo 29 del Decreto Ley $\mathrm{N}^{\circ} 211$. "Las normas contenidas en los Libros I y II del Código de Procedimiento Civil se aplicarán supletoriamente al procedimiento mencionado en los artículos precedentes, en todo aquello que no sean incompatibles con él". Artículo 385, inciso primero CPC. "Fuera de los casos expresamente previstos por la ley, todo litigante está obligado a declarar bajo juramento, contestada que sea la demanda, sobre hechos pertenecientes al mismo juicio, cuando lo exija el contendor o lo decrete el tribunal en conformidad al artículo 159”.
} 
FERNÁNDEZ, José. “Los apremios personales en la jurisprudencia del Tribunal Constitucional: un análisis crítico desde la dogmática de los principios y límites penales”.

causa criminal. ${ }^{94}$ Sin perjuicio de ello, deja la puerta abierta precisando que esta garantía podría extenderse a causas no criminales o procedimientos administrativos que afectaren la libertad, si el propio TC la considera parte del debido proceso $^{95}$ y con ello no se afecta su contenido esencial, el que vendría dado por la existencia de un sujeto (imputado o acusado de un delito) y una acción (declarar sobre hecho propio). ${ }^{96}$

Por último, el TC desestima una infracción al derecho de defensa, pues este derecho “(...) no comprende el acceso a todas y cada una de las garantías disponibles en cualquier tipo de proceso, sino solo aquellas que pueden entenderse derivadas directamente del mandato constitucional y aquellas que el Legislador ha establecido en conformidad con el mandato del artículo 19, número 3, inciso sexto, de la Carta Fundamental". ${ }^{97}$ Además, el TC señala que el derecho de defensa estaría suficientemente resguardado en las causas seguidas ante el Tribunal de Defensa de la Libre Competencia ${ }^{98}$, y en un eventual proceso penal. ${ }^{99}$

\section{Análisis crítico de la jurisprudencia del Tribunal Constitucional sobre los apremios personales.}

Una vez examinados los argumentos de las sentencias del TC, haciendo un balance, se aprecia que este, mayoritariamente, ha sostenido que la regulación de los apremios personales -en diversas áreas del derecho- es constitucional, ya que se trataría de medidas de compulsión, desvinculadas del ámbito penal, dictadas por los tribunales de justicia como concreción de la potestad de imperio que les reconoce la Constitución (Art. 76). También considera, en general, que no estamos ante injerencias a los derechos fundamentales desproporcionadas o vulneradoras del debido proceso. Esta doctrina ha sido permanente en el TC. Con todo, se observan avances en la extensión y aplicación de algunas garantías constitucionales penales a los apremios personales.

El TC, en tres oportunidades ha declarado inaplicables preceptos sobre apremios. En estos fallos el TC ha considerado que los apremios impugnados: (i) no superaban el juicio de proporcionalidad, ${ }^{100}$ (ii) no constituían un genuino apremio sino una pena privativa de libertad, ${ }^{101} \mathrm{y}$, (iii) vulneraban garantías y principios consagrados en la Carta Fundamental. ${ }^{102}$

Estas sentencias contienen argumentos que pudieran haberse extendido a otras situaciones, por ello, y ante la existencia de numerosas razones para cuestionar la constitucionalidad de los apremios personales, la doctrina mayoritaria del TC es susceptible de recibir numerosas críticas. En todo caso, debemos advertir que la jurisprudencia del TC sobre los apremios personales constituye, junto a la emanada del principio de tipicidad, una de las mejor

\footnotetext{
94 Tribunal Constitucional, Rol 2381-12, 20 de agosto de 2013, considerando 10.

95 Tribunal Constitucional, Rol 2381-12, 20 de agosto de 2013, considerandos 11 al 13.

96 Tribunal Constitucional, Rol 2381-12, 20 de agosto de 2013, considerando 13.

97 Tribunal Constitucional, Rol 2381-12, 20 de agosto de 2013, considerando 36.

98 Tribunal Constitucional, Rol 2381-12, 20 de agosto de 2013, considerando 37.

99 Tribunal Constitucional, Rol 2381-12, 20 de agosto de 2013, considerando 38.

100 Tribunal Constitucional, Rol 1145-08, 17 de marzo de 2009.

101 Tribunal Constitucional, Rol 1518-09, 21 de octubre de 2010.

102 Tribunal Constitucional, Rol 2216-12, 22 de enero de 2013.
} 
Polít. crim. Vol. 13, No 25 (Julio 2018) Art. 10, pp. 350-386.

[http://www.politicacriminal.c1/Vol_13/n_25/Vol13N25A10.pdf]

argumentadas no solo desde la dogmática constitucional, sino también desde la dogmática de los principios y límites penales.

A continuación, se expondrán estas críticas sistematizadas a partir de los principios y garantías penales implicadas y de la incidencia los tratados internacionales sobre derechos humanos.

\subsection{Límites al ius puniendi consagrados en la Constitución}

\subsubsection{Principio de legalidad.}

Un punto conflictivo en este ámbito es el relativo a la naturaleza jurídica de los apremios personales. Aquí se observa un excesivo formalismo por parte del TC, es decir, una estricta sujeción al texto de la ley y a la historia de su establecimiento, con el fin de sustraer completamente a estos apremios de los principios y garantías penales. Si bien, acertadamente, el TC ha sostenido que el apremio de arresto no es lo mismo que la detención o la prisión preventiva, igualmente, como se señalara en la primera parte de este trabajo, ${ }^{103}$ existen suficientes razones para afirmar una estrecha vinculación entre las normas sobre apremios y el derecho penal. No obstante, no debemos olvidar la sentencia Rol 1518 que, a partir de una interpretación material del artículo 169 del Código Sanitario, concluyó que esta norma no contenía un apremio sino una pena "administrativa".

También, puede cuestionarse la interpretación analógica que el TC realiza respecto al alcance de la excepción a la prohibición de la prisión por deudas contenida en la $\mathrm{CADH}$, aplicada al incumplimiento de la obligación de pago de cotizaciones previsionales y de compensación económica, so pretexto del carácter alimenticio que les atribuye en razón de estar establecidas a favor del más débil. Nos encontramos ante una interpretación analógica en contra del reo, que además plantea la interrogante si esta prohibición se extiende, no solo a los tribunales ordinarios, sino también al propio TC. ${ }^{104}$ La respuesta debiera ser afirmativa, si se considera lo dispuesto en el capítulo I de nuestra Constitución, que consagra, entre otros, el principio de supremacía constitucional y su consiguiente vinculación a "todos los órganos del Estado" (artículo 6 CPR).

\subsubsection{Principio de proporcionalidad.}

El TC, progresivamente, ha aplicado el principio de proporcionalidad y por esta vía otros límites al ius puniendi como los principios de mínima intervención y subsidiariedad, para determinar la constitucionalidad de los apremios que han sido impugnados vía recurso de inaplicabilidad. Sin embargo, la aplicación del principio de proporcionalidad como test de constitucionalidad ha sido parcial y carente de orden, pues no se han aplicado todos los presupuestos y subprincipios que este comprende, ${ }^{105} \mathrm{o}$ se ha hecho mediante declaraciones retóricas de escaso contenido, tales como: "la medida de apremio resulta idónea y eficaz para la obtención de un fin lícito". De esta forma, el juicio de proporcionalidad ha sido

\footnotetext{
${ }^{103}$ Supra, 1.3.

${ }^{104}$ FERNÁNDEZ, “Tribunal Constitucional”, cit. nota n 23, pp. 223-224.

105 FERNÁNDEZ, “Tribunal Constitucional”, cit. nota $n^{\circ} 23$, p. 229.
} 
FERNÁNDEZ, José. "Los apremios personales en la jurisprudencia del Tribunal Constitucional: un análisis crítico desde la dogmática de los principios y límites penales”.

mayoritariamente empleado para justificar la constitucionalidad del apremio de arresto en los casos concretos sometidos a su conocimiento, a pesar de existir numerosas razones en contra, ${ }^{106}$ en especial, sobre la necesidad y proporcionalidad de la medida. A lo anterior debemos añadir que la argumentaciones esgrimidas por el TC para declarar inaplicable varios apremios fundamentada en la necesidad y proporcionalidad pueden extenderse a una gran parte de los casos que ha considerado conformes con la Constitución.

Cuestionamos también de la distinción entre obligaciones civiles y legales para justificar la legitimidad del fin perseguido por la medida de apremio, principalmente, en relación al cumplimiento de los tratados internacionales. Estamos ante una mera distinción formal que depende, por ejemplo, de una sentencia judicial que establezca la obligación de pagar una determinada deuda, como ocurre en el caso del Art. 238 CPC; o que la deuda afecte a intereses públicos como en el caso del artículo 28 del Decreto Ley 211 respecto del condenado al pago de una multa por el Tribunal de Defensa de la Libre Competencia que no acreditare su pago. Si no se determina la importancia del interés o bien jurídico afectado, entonces nos encontramos ante una discriminación arbitraria a la hora de aplicar una privación de libertad. En este ámbito, el principio de exclusiva protección de bienes jurídicos constituye, como expresión del juicio de necesidad, un instrumento adecuado para excluir ciertas conductas del ordenamiento jurídico. ${ }^{107}$

Si ya resulta discutible que se pueda imponer una pena privativa de libertad en el caso del incumplimiento de una pena de multa, mucho menos justificable es el ingreso en prisión por el no pago de una deuda u obligación "legal". En este sentido la Corte Suprema estadounidense ha establecido que un Estado de la Unión no puede imponer términos discriminatorios meramente por el hecho de que la deuda sea pública y no privada. Añade que la posibilidad de aplicar un apremio personal por el mero hecho de la naturaleza pública de la deuda puede conllevar privaciones de libertad que, en último término, se encuentran condicionadas por la condición de pobreza del deudor. ${ }^{108}$

Relacionado con la anterior crítica, resulta discutible la alusión a un interés público a la hora de legitimar el fin perseguido por la norma. La utilización de este tipo de conceptos como el "interés general" o el "bien común", que en apariencia constituyen parámetros objetivos, puede ser un medio que permita introducir más fácilmente concepciones subjetivas y

\footnotetext{
${ }^{106}$ Esta situación ha sido advertida por la doctrina, por ejemplo, Gloria Lopera ha señalado que "(...) llama la atención que, en las sentencias en las que [el TC] se ocupa del control de normas penales, la utilización selectiva y asistemática de algunos subprincipios de la proporcionalidad, en lugar de servir como insumo para incrementar la racionalidad de la fundamentación, se convierte en mampara retórica para evadir la exigencia de dar razones que avalen la constitucionalidad de las normas impugnadas". LOPERA, Gloria, "Principio de proporcionalidad y control constitucional de las leyes penales. Una comparación entre las experiencias de Chile y Colombia". Revista de Derecho Universidad Austral de Chile, Vol. XXIV, № 2 (2011), pp. 113-138, p. 124. ${ }^{107}$ FERNÁNDEZ, José, "El juicio constitucional de proporcionalidad de las leyes penales: ¿La legitimación democrática como medio para mitigar su inherente irracionalidad?”, Revista de Derecho Universidad Católica del Norte, $\mathrm{N}^{\mathrm{o}} 1$ (2010), pp. 51-99, p. 77. Ahora bien, como veremos en un posterior apartado, si nos encontramos ante una afección grave a un bien jurídico fundamental, como podría ser conjunto de condiciones susceptibles de garantizar una vida digna en el caso del impago de deberes alimentarios, entonces la cuestión no es dilucidar la legitimidad del apremio, sino la de la tipificación de un delito.

108 HAMPSON, Christopher, "State Bans on Debtors' Prisons and Criminal Justice Debts", Harvard Law Review, vol. 129 (2016), pp. 1024-1045.
} 
Polít. crim. Vol. 13, № 25 (Julio 2018) Art. 10, pp. 350-386.

[http://www.politicacriminal.cl/Vol_13/n_25/Vol13N25A10.pdf]

apreciaciones personales, que sean finalmente las que resuelvan un conflicto constitucional. ${ }^{109}$ De ahí que su invocación también requiera un esfuerzo argumentativo por parte del TC.

En relación a la adecuación de la medida de apremio para la consecución de un objetivo legítimo, se aprecia que el TC ha adoptado una versión débil del examen de idoneidad, estimando sin mayores reparos que el apremio personal resulta una medida idónea para obtener el cumplimiento de una resolución judicial y, en su caso, dar eficacia a derechos de terceras personas. En la fundamentación de este juicio de constitucionalidad, el TC ha omitido, en la mayor parte de sus fallos, una alusión a la utilidad de la intervención penal, demostrando el daño social del incumplimiento de las obligaciones "legales" y la eficacia atribuida a una privación de libertad para evitar el apremio. Tampoco se ha considerado la experiencia extranjera y/o estadísticas al respecto. ${ }^{110}$

En cuanto a la necesidad de la medida, el TC, de acuerdo con el principio de mínima intervención, al recalcar que el arresto es adoptado como una medida extrema y excepcional. En este sentido, ha establecido de manera acertada, la existencia de otros medios eficaces para la consecución de los fines que atribuye a las normas sobre apremios, por ejemplo, el derecho de prenda general. Sin embargo, con excepción de la sentencia Rol 2216-12 y la prevención de los ministros Bertelsen y Correa en la sentencia Rol 1145-08, ello no ha sido suficiente para descartar la necesidad de esta medida privativa de libertad en otros casos.

Respecto al examen de proporcionalidad en sentido estricto, la situación es aún más desalentadora. El TC mayoritariamente ha considerado que la consecuencia jurídica con que se retribuye el incumplimiento de una resolución judicial es proporcionada, tanto así que en la sentencia Rol 1971-11, estimó que un arresto como apremio que puede extenderse por dos meses, renovable, constituía una restricción a la libertad personal "muy limitada en el tiempo", pues el requirente podría evitar su aplicación cumpliendo con lo ordenado en la sentencia. Todo lo expuesto en cuanto a la aplicación del principio de proporcionalidad en la jurisprudencia estudiada, contribuye a evidenciar la necesidad de un control más riguroso tratándose de normas que afectan con la misma intensidad a los derechos fundamentales que las privaciones de libertad reguladas en el derecho penal y procesal penal. Ahora bien, conviene precisar que el TC ha sido mucho más deferente en materia penal, en especial, en cuanto a la proporcionalidad de las penas, respecto de los apremios que, como hemos visto, ha declarado inaplicable alguno de ellos. ${ }^{111}$

\subsubsection{Garantías del debido proceso.}

Respecto a la aplicación del derecho al debido proceso en la jurisprudencia estudiada, el debate ha consistido principalmente en determinar qué garantías de este derecho son

109 ARNOLD, Rainer; MARTÍNEZ, José; ZÚÑIGA, Francisco, "El principio de proporcionalidad en la jurisprudencia del Tribunal Constitucional”, Estudios Constitucionales, Universidad de Talca, $\mathrm{N}^{\circ} 1$ (2012), pp. 65-116, p. 85.

${ }^{110}$ FERNÁNDEZ, "El juicio", cit. nota no 108, pp. 80-82.

${ }^{111}$ A la fecha, la STC Rol 2936-INA, 20 de octubre de 2016, referida al Art. 195. 1 bis de la Ley $\mathrm{N}^{\circ} 20.770$, es la única ocasión en que ha declarado inaplicable una norma penal fundamentada, entre otros razonamientos, en el principio de proporcionalidad. 
FERNÁNDEZ, José. “Los apremios personales en la jurisprudencia del Tribunal Constitucional: un análisis crítico desde la dogmática de los principios y límites penales”.

aplicables a los procedimientos en que estos se decretan. Si bien, las infracciones al debido proceso, han servido para declarar la inaplicabilidad varios apremios, el TC, con carácter general, ha descartado una vulneración al debido proceso, sustentándose en las competencias del legislador atribuidas constitucionalmente. Así, sería el legislador quien habría decidido no hacer extensivas algunas garantías del debido proceso a estos procedimientos y, por tanto, no le correspondería tampoco al TC cuestionarlo.

Ahora bien, teniendo presente la comprensión de los apremios personales como una privación de libertad, y que esta limitación a los derechos fundamentales es la que fundamenta nuestro sistema de garantías procesales penales, no se encuentra ninguna razón para omitir garantías como el derecho a ser oído ante un tribunal, la presunción de inocencia, y la revisión de lo fallado por un tribunal superior.

En cuanto al derecho a ser oído, el TC no considera en sus argumentaciones que, en la mayoría de los procedimientos en que se decretan apremios, no se cita al afectado a una audiencia, a excepción de los apremios contemplados en el Código Tributario; ${ }^{12}$ ni tampoco se le otorgan plazos adecuados para defenderse. Lo anterior pugna con el derecho de toda persona a ser oída (artículo 8.1 CADH) y constituye una conculcación del principio de bilateralidad de la audiencia.

En consonancia con lo anterior, es aún más criticable que el TC, en su planteamiento mayoritario, no haya advertido una vulneración a la presunción de inocencia, so pretexto de justificar el apremio en el hecho de que se basa en un incumplimiento eventualmente constitutivo de delito. Bajo ese planteamiento, el apremio constituiría una "prisión provisional". ${ }^{113}$ En efecto, son plenamente extensibles a otro tipo de apremios las consideraciones expresadas en la sentencia Rol 2216-12 y los razonamientos minoritarios que ministros del TC han realizado, propugnando por la vigencia de esta y otras garantías en un procedimiento cuyo fin es sancionar el incumplimiento de resoluciones judiciales.

Respecto al carácter inapelable de la resolución que decreta un apremio, el TC no considera que dicho carácter pueda ser constitutivo de una diferencia arbitraria atentatoria contra el principio de igualdad (artículo 19, $\mathrm{N}^{\circ} 2$ CPR). Nosotros, por el contrario, entendemos que podría vulnerarse el citado precepto constitucional, ya que, en algunos casos, se dejaría a quien es privado de libertad en una situación más desfavorable que al solicitante del apremio, quien sí podría interponer un recurso de apelación.

En síntesis, el TC debió constatar los vicios de inconstitucionalidad que adolecen los procedimientos en que se decretan apremios personales, fijando un estándar mínimo, similar al contemplado en el CPP para la imposición de privaciones de libertad, en el que se reconozca el derecho a ser oído, la presunción de inocencia y el derecho al recurso.

\footnotetext{
112 Por ejemplo, tratándose del cobro de prestaciones de seguridad social, el artículo 12 de la Ley 17.322 dispone que "El apremio será decretado, a petición de parte, por el mismo Tribunal que esté conociendo de la ejecución y con el solo mérito del certificado del secretario que acredite el vencimiento del término correspondiente y el hecho de no haberse efectuado la consignación" (las cursivas son nuestras).

${ }^{113}$ FERNÁNDEZ, José, "Tribunal Constitucional”, cit. nota $n^{\circ} 23$, p. 221.
} 
Polít. crim. Vol. 13, № 25 (Julio 2018) Art. 10, pp. 350-386.

[http://www.politicacriminal.c1/Vol_13/n_25/Vol13N25A10.pdf]

\subsection{Tratados internacionales sobre derechos humanos.}

Los tratados internacionales, específicamente, los de derechos humanos cada vez adquieren más importancia en nuestro ordenamiento jurídico, a la luz de lo dispuesto en el artículo 5 inciso segundo CPR. En todo caso, debe precisarse que el TC ha cuestionado la jerarquía de estos instrumentos y su ámbito de aplicación. ${ }^{114}$

En este análisis jurisprudencial, ya se han mencionado algunos aspectos relacionados con el derecho internacional, razón por la cual, en este apartado se hará mención a otros: la interpretación de las disposiciones de derecho internacional, en este caso, de la prohibición de la prisión por deudas, y el carácter de parámetro de control de los tratados internacionales.

En relación a lo primero, el TC ha afirmado mayoritariamente que la proscripción internacional del encarcelamiento por deudas, contenida en el PIDCP, la DADDH y la $\mathrm{CADH}$, se extiende exclusivamente a deudas de origen contractual. Esta interpretación, tal como sostuviera el ministro Venegas en un voto disidente, ${ }^{115}$ es altamente cuestionable, pues, en conformidad al artículo 29 de la $\mathrm{CADH},{ }^{116}$ las disposiciones de esta Convención deben interpretarse a luz del principio pro homine o pro libertate, es decir, de manera amplia, extendiendo sus efectos a todo tipo de obligaciones. Lo anterior está en sintonía con la necesidad de una interpretación teleológica del derecho internacional de los derechos humanos que asegure la mayor protección al afectado ${ }^{117}$ con independencia del origen o título del que proceda la obligación.

Sobre la aptitud de los tratados internacionales de derechos humanos para servir como parámetro de control de constitucionalidad, llama la atención la tesis sostenida en la sentencia Rol 2265-12, en orden a que estos no constituyen un parámetro de control autónomo. Con

\footnotetext{
114 Luis Castillo ha mantenido que la convivencia de disposiciones de derechos humanos provenientes del derecho internacional y disposiciones constitucionales en el sistema constitucional interno, debe solucionarse conjugando tres principios hermenéuticos: el principio de unidad de los derechos humanos, el principio de unidad normativa y el principio de unidad aplicativa. Este último prescribe que "las normas de las disposiciones de una Convención o de una Constitución que recogen derechos humanos, han de ser aplicadas como conformantes todas ellas de un sistema jurídico coherente y unitario, de modo que, en los hechos, la solución de los casos concretos no pueda suponer restricciones o sacrificios (del contenido esencial) de los derechos humanos". CASTILLO, Luis, "La relación entre los ámbitos normativo internacional y nacional sobre derechos humanos", Estudios constitucionales, № 2 (2012), pp. 231-280, pp. 252-253.

115 Tribunal Constitucional, Rol 2102-11, 27 de septiembre de 2012 (voto en contra del ministro Marcelo Venegas).

116 Artículo 29 CADH. Normas de Interpretación. Ninguna disposición de la presente Convención puede ser interpretada en el sentido de:

a) permitir a alguno de los Estados Partes, grupo o persona, suprimir el goce y ejercicio de los derechos y libertades reconocidos en la Convención o limitarlos en mayor medida que la prevista en ella;

b) limitar el goce y ejercicio de cualquier derecho o libertad que pueda estar reconocido de acuerdo con las leyes de cualquiera de los Estados Partes o de acuerdo con otra convención en que sea parte uno de dichos Estados;

c) excluir otros derechos y garantías que son inherentes al ser humano o que se derivan de la forma democrática representativa de gobierno, $\mathrm{y}$

d) excluir o limitar el efecto que puedan producir la Declaración Americana de Derechos y Deberes del Hombre y otros actos internacionales de la misma naturaleza.

117 ALDUNATE, Nombre, Derechos fundamentales, Santiago: Legal Publishing, 2008, p. 129.
} 
FERNÁNDEZ, José. “Los apremios personales en la jurisprudencia del Tribunal Constitucional: un análisis crítico desde la dogmática de los principios y límites penales”.

este planteamiento, el TC no considera los argumentos elaborados por la doctrina que atribuyen a los tratados internacionales sobre derechos humanos al menos jerarquía constitucional. ${ }^{118}$ En todo caso, si aceptamos la tesis seguida por la citada sentencia, podría plantearse en el futuro la inconstitucionalidad del apremio por impago de deberes alimentarios, al entender que, a pesar de encontrarse expresamente permitida en el Artículo $7 \mathrm{~N}^{\circ} 7$ del Pacto de San José de Costa Rica, vulnera alguna disposición de nuestra Constitución.

Finalmente, también es cuestionable la no recepción del denominado control de convencionalidad por parte del TC. ${ }^{119}$ En efecto, el TC se ha limitado a realizar un control de constitucionalidad, ${ }^{120}$ ignorando, además, pronunciamientos de la Corte Interamericana de Derechos Humanos que podrían ser utilizados en el tema que nos ocupa, y que han tenido, precisamente, como referentes normativos el principio de proporcionalidad respecto de limitaciones a la libertad personal (artículo $7^{\circ} \mathrm{CADH}$ ) y a las garantías judiciales (artículo 8 $\mathrm{CADH}) .{ }^{121}$

\section{Conclusión y propuestas de reforma.}

La problemática de los apremios personales en Chile no debería solventarse a través de una adecuada aplicación de los principios y garantías penales por parte del TC, sino a través de una intervención activa del Legislador. Estamos ante una anomalía jurídica del tal calibre que resulta necesario una reforma estructural. Las limitaciones competenciales, institucionales y epistemológicas a las que se ve sometido el TC hacen difícil, sino imposible, que este pueda determinar los casos en que resulta necesario acudir a una privación de libertad como consecuencia del incumplimiento de ciertas obligaciones.

La primera medida resulta simple y sencilla: la derogación de los apremios personales en el derecho chileno. El mero hecho de incumplir una obligación o una resolución judicial no puede por sí misma justificar privación de libertad de una persona.

\footnotetext{
118 CASTILLO, Luis, “La relación”, cit. nota n ${ }^{\circ} 115$, p. 250.

119 Para un análisis del concepto, fundamentos jurídicos y aplicación del control de convencionalidad en la jurisprudencia del Tribunal Constitucional, NOGUEIRA, Humberto, "Diálogo interjurisdiccional, control de convencionalidad y jurisprudencia del Tribunal Constitucional en período 2006-2011", Estudios Constitucionales, $\mathrm{N}^{\circ} 2$ (2012), pp. 57-140.

${ }^{120}$ La necesidad y beneficios del control de convencionalidad han sido resaltados por NOGUEIRA, "Diálogo interjurisdiccional", cit. nota ${ }^{\circ} 120$, p. 85.

${ }^{121}$ Corte Interamericana de Derechos Humanos, Caso Usón Ramírez vs. Venezuela, 20 de noviembre de 2009. Esta sentencia tiene bastantes argumentos que pudieron ser empleados por el TC en las sentencias estudiadas, en ella, la Corte Interamericana realiza un análisis detallado de eventuales infracciones al principio de legalidad, la libertad de expresión, las garantías judiciales, la protección judicial, la libertad personal y el deber de adoptar disposiciones de derecho interno, empleando el principio de proporcionalidad. Por ejemplo, en cuanto a la libertad personal, en el considerando 146 del fallo, la Corte sostuvo: "En lo que respecta a la arbitrariedad referida en el artículo 7.3 de la Convención, la Corte ha establecido en otras oportunidades que nadie puede ser sometido a detención o encarcelamiento por causas y métodos que -aún calificados de legales- puedan reputarse como incompatibles con el respeto a los derechos fundamentales del individuo por ser, entre otras cosas, irrazonables, imprevisibles o faltos de proporcionalidad".
} 
Polít. crim. Vol. 13, No 25 (Julio 2018) Art. 10, pp. 350-386.

[http://www.politicacriminal.c1/Vol_13/n_25/Vol13N25A10.pdf]

Ahora bien, esto no significa que el incumplimiento de algunas de estas obligaciones no requiera una sanción de naturaleza pública y, en concreto, penal; o que otros se transformen en otro tipo de apremios. En aquellos casos, en que los que se vean especialmente comprometidos intereses públicos podrá plantearse la tipificación de un delito, como ocurre, en el derecho comparado en los casos de impago de pensiones alimenticias (Art. $227 \mathrm{CP}$ español). Así, en el caso español, no se problematizado sobre la conveniencia de retomar los apremios personales, ni mucho menos sobre la necesidad de acudir a las nuevas manifestaciones de la prisión por deudas reguladas en el derecho estadounidense. Lo único que se ha discutido, desde una perspectiva constitucional, es si, a pesar de estar tipificado como delito, se continúa vulnerando la prohibición de prisión por deudas o si existen otras medidas más idóneas distintas a la privación de libertad, para asegurar el impago de las pensiones alimenticias. ${ }^{122}$

El derecho penal y procesal penal deberían ser las únicas ramas del ordenamiento jurídico que contemplaran privaciones de libertad de un ciudadano. Por tanto, la única privación de libertad anticipada que cabría sería la prisión provisional. Esta última opción parece más aconsejable, pues permite conciliar la satisfacción de los derechos e intereses en conflicto con los derechos fundamentales del afectado, entre otros, el principio de legalidad, el principio de ofensividad, el derecho a ser oído, la presunción de inocencia, la revisión de lo fallado por un tribunal superior, la motivación de las sentencias, etc. Si partimos de esta propuesta de reforma legislativa, surge la cuestión, desde una perspectiva orgánica, sobre qué tribunal o jurisdicción debe de conocer estos apremios (delitos): los tribunales penales chilenos o, por el contrario, el resto de los tribunales ordinarios (familia, laboral o civil) que conoce del incumplimiento que origina esta medida privativa de libertad. Esta interesante cuestión, excede las pretensiones de este estudio, pero, sin duda, constituye una cuestión insoslayable en la necesaria reforma de los denominados apremios personales.

$\mathrm{Si}$ aceptamos la tesis seguida por el TC de que los apremios personales tienen como presupuesto el incumplimiento de una obligación legal o civil, entonces y para evitar la tipificación encubierta de delitos de mera desobediencia, debemos preguntarnos si, de acuerdo con el principio de ofensividad nos encontramos ante una conducta merecedora de una privación de libertad. Como puede apreciarse, la única salida es determinar qué apremios contemplados en nuestro ordenamiento jurídico merecen una protección penal. ${ }^{123}$ Esto supone una reinterpretación de la prohibición establecida en el artículo 7.7 CIDH en el sentido que lo realmente prohibido es la prisión por el mero incumplimiento de una deuda u

\footnotetext{
${ }^{122}$ Véase en extenso y doctrina citada en: COLÁS, Asunción, "Breve reflexión sobre el delito de impago de pensiones, art. 227 CP”, Revista Boliviana de Derecho, no 17 (2014), pp. 210-229.

123 Ahora bien, esta exigencia no puede eludirse estableciendo como bien jurídico protegido el buen funcionamiento de la Administración de Justicia, porque esto supondría, en último término, que cualquier incumplimiento de una sentencia judicial conllevaría aparejada una pena de prisión. Así, por ejemplo, en el caso del impago de deberes alimentarios, la integridad personal de los beneficiados por las prestaciones, es decir, el conjunto de condiciones susceptibles de garantizar una vida digna, constituiría el bien jurídico que podría ameritar una protección penal. La identificación de este bien jurídico refleja el principal menoscabo a un interés social digno de protección penal y, como manifiesta Brage, "resulta especialmente útil a la hora de precisar qué hechos pueden integrarse en este tipo delictivo y cuáles pueden rechazarse por no atender a la protección de dicho bien jurídico". BRAGE, Santiago, "El delito de impago de pensiones (artículo 227 CP)", Revista Xurídica Calega, no 36 (2002), p. 13-26, p. 15.
} 
FERNÁNDEZ, José. “Los apremios personales en la jurisprudencia del Tribunal Constitucional: un análisis crítico desde la dogmática de los principios y límites penales”.

obligación cualquiera sea su naturaleza, requiriéndose una afectación grave a un bien jurídico de especial interés.

Ahora bien, no podemos desconocer que una de las principales ventajas de los apremios consiste en que permite evitar la privación de libertad si se cumple con la obligación legal y, de esta manera, satisfacer de mejor manera con el especial interés social (bien jurídico) que se pretende proteger. Esta situación podría solventarse con la inclusión de una causa de exclusión de la punibilidad (excusa absolutoria) o/y la posibilidad de aplicar una suspensión condicional del procedimiento o un acuerdo reparatorio. Efectivamente, estamos ante una circunstancia fundamentada en el comportamiento posterior a la infracción de la norma penal dirigido a evitar o mitigar el menoscabo al bien jurídico protegido por la norma. Una cuestión relevante radica en determinar en el momento procesal en el que pudiera operar esta excusa absolutoria. Entendemos que, en los casos en que se pretende tutelar un especial interés público, esta podría operar después de la interposición de la denuncia, querella o formalización. No obstante, esta posibilidad solo podría operar por una sola vez. También, sería conveniente introducir en la descripción del tipo penal un requisito de habitualidad, ya que, en este tipo de conductas reguladas por otras ramas del ordenamiento jurídico se debe ser especialmente cuidadosos con los principios de subsidiariedad, última ratio y fragmentariedad del derecho penal. ${ }^{124}$

Ahora bien, en el intertanto, resulta necesario ahondar en la elaboración de criterios de interpretación que permitan, en la medida de lo posible, conciliar este tipo de privaciones de libertad con los derechos y garantías constitucionales. En este sentido, el Tribunal Constitucional debería continuar, profundizar y ampliar en los criterios de interpretación fundamentados en el juicio de proporcionalidad y las garantías derivadas del debido proceso.

No obstante, pueden añadirse otras reglas interpretativas que permitan mitigar el peligro que subyace de todo apremio personal: la prohibición de la prisión por deudas y, especialmente, evitar que la pobreza sea la causa latente en la aplicación de un apremio personal. Aquí, puede ser de marcado interés la jurisprudencia estadounidense relativa a las limitaciones a la prisión por incumplimiento de obligaciones monetarias. Como podrá apreciarse, estas reglas pueden reconocerse tanto en sede judicial ordinaria como en sede constitucional (inaplicabilidad). Así, un apremio personal no debería aplicarse cuando el deudor haya hecho todo lo necesario para poder afrontar el cumplimiento de la obligación de acuerdo con el principio de buena fe. Desde la dogmática penal de corte continental, esta regla interpretativa consistiría en la exigencia de una capacidad personal de acción, condición de aplicación requerida para delitos omisivos, estructura típica que coincide con la mayor parte de los apremios personales. Por tanto, será atípica si el obligado carece de los medios materiales necesarios para hacer frente a la obligación. ${ }^{125}$

En este sentido, la Corte Suprema estadounidense ha establecido la obligación de que los tribunales de justicia incorporen una audiencia en el que se examine la capacidad financiera para pagar la deuda. Esto significa que el apremio solo puede aplicarse cuando en esta

\footnotetext{
${ }^{124}$ Véase en este sentido el Art. 227 CP español, cit. nota ${ }^{\circ} 25$.

${ }^{125}$ Así, véase respecto del delito de impago de pensiones del artículo 227 Código penal español, BRAGE, "El delito", cit. nota ${ }^{\circ} 124$, p. 18 .
} 
Polít. crim. Vol. 13, № 25 (Julio 2018) Art. 10, pp. 350-386.

[http://www.politicacriminal.c1/Vol_13/n_25/Vol13N25A10.pdf]

audiencia quede probado el incumplimiento doloso de la obligación. En este sentido, algunos tribunales han establecido una presunción de indigencia cuando los bienes o capacidad económica del obligado no superan una cierta cantidad de ingresos. ${ }^{126}$

${ }^{126}$ HAMPSON, “State Bans”, cit. nota n 109, pp. 1024-1045. 
FERNÁNDEZ, José. "Los apremios personales en la jurisprudencia del Tribunal

Constitucional: un análisis crítico desde la dogmática de los principios y límites penales”.

\section{Bibliografía}

ACTAS DE LA COMISIÓN DE ESTUDIO DE LA NUEVA CONSTITUCIÓN, Sesión 107, 18 de marzo de 1975, pp. 636 - 666.

ALDUNATE, Eduardo, Derechos fundamentales, Santiago: Legal Publishing, 2008.

ANABALÓN, Carlos, Tratado práctico de derecho procesal civil chileno: vol. 1, 2ª Edición, Concepción: Librotec, 1966.

ARANCIBIA, Jaime, "Cumplimiento de sentencias que ordenan pagar una suma de dinero al Fisco", en: ARANCIBIA, Jaime; MARTÍNEZ, José; ROMERO, Alejandro (Coords.), Litigación Pública, Santiago: Thomson Reuters, 2011, pp. 515-557.

ARNOLD, Rainer; MARTÍNEZ, José; ZÚÑIGA, Francisco, “El principio de proporcionalidad en la jurisprudencia del Tribunal Constitucional", Estudios Constitucionales, Universidad de Talca, $\mathrm{N}^{\circ} 1$ (2012), pp. 65-116.

BERNAL, Carlos, El principio de proporcionalidad y derechos fundamentales, Madrid: Centro de Estudios Constitucionales, 2005.

BRAGE, Santiago, "El delito de impago de pensiones (Art. 227 CP)", Revista Xurídica Calega, no 36 (2002), pp. 13-26.

BUSTOS, Juan; HORMAZÁBAL, Hernán, Lecciones de derecho penal chileno, Santiago: Librotecnia, 2012.

CASTILLO, Luis, "La relación entre los ámbitos normativo internacional y nacional sobre derechos humanos”, Estudios Constitucionales, № 2 (2012), pp. 231-280.

CEA, J., Derecho constitucional chileno. Tomo II: Derechos, deberes y garantías, Santiago: Ediciones Universidad Católica de Chile, 2003.

COLÁS, Asunción, "Breve reflexión sobre el delito de impago de pensiones, art. 227 CP", Revista Boliviana de Derecho, no 17 (2014), pp. 210-229.

COLOMBO, Juan, El debido proceso constitucional, trabajo preparado para el encuentro anual de la Corte Constitucional Italiana, Roma, diciembre, 2003, pp. 1-141. Disponible en: http://www.tribunalconstitucional.cl/wp/documentos/buscador-de-documentos. Consultado el 9 de noviembre de 2016.

CURY, Enrique, Derecho penal. Parte general, Santiago: Ediciones Universidad Católica de Chile, 2005.

DOMÍNGUEZ, Ramón, “Apremio por no pago de imposiciones. ¿Prisión por deudas?", Revista de derecho Universidad de Concepción, № 214 (2003), pp. 188-194. 
Polít. crim. Vol. 13, № 25 (Julio 2018) Art. 10, pp. 350-386.

[http://www.politicacriminal.c1/Vol_13/n_25/Vol13N25A10.pdf]

ETCHEBERRY, Alfredo, Derecho penal. Parte general: Tomo I, Santiago: Editorial Jurídica de Chile, 1998.

FERNÁNDEZ, José, "El juicio constitucional de proporcionalidad de las leyes penales: ¿La legitimación democrática como medio para mitigar su inherente irracionalidad?", Revista de Derecho Universidad Católica del Norte, No 1 (2010), pp. 51-99.

FERNÁNDEZ, José, “Tribunal Constitucional y derecho penal: un estudio crítico", Revista Estudios Constitucionales, año 12, N 2 (2014), pp. 187-238.

GARCÍA, Ana, "Justicia constitucional y prohibición internacional de la prisión por deudas", en: NUÑEZ, Manuel (Ed.), La internacionalización del derecho público. Actas XLII Jornadas Chilenas de Derecho Público, Santiago: Thomson Reuters, 2015, pp. 471-491.

GARRIDO, Mario, Derecho penal. Parte general: Tomo I, Santiago: Editorial Jurídica de Chile, 2001.

HAMPSON, Christopher, "State Bans on Debtors' Prisons and Criminal Justice Debts", Harvard Law Review, vol. 129 (2016), pp. 1024-1045.

HERNÁNDEZ, Héctor, "Alcances del delito de desacato en el contexto de la Ley de Violencia Intrafamiliar", Informes en Derecho, Santiago: Defensoría Penal Pública, 2011, pp. 5-12.

HISTORIA DE LA LEY 20.724, modifica el Código Sanitario en materia de regulación de farmacias y medicamentos, pp. 1-1092.

LATANA, Gabriela, "El apremio de arresto contemplado en el artículo 12 de la Ley 17.322 ¿Prisión por deudas?”, Revista de Derecho (Universidad de Concepción), 2013, pp.143155.

LOPERA, Gloria, "Principio de proporcionalidad y control constitucional de las leyes penales. Una comparación entre las experiencias de Chile y Colombia", Revista de Derecho Universidad Austral de Chile, Vol. XXIV, Nº 2 (2011), pp. 113-138.

MOLINA, Hernán, Derecho Constitucional, Santiago: Legal Publishing, 2010.

NOGUEIRA, Humberto, Derechos fundamentales y garantías constitucionales: Tomo II, Santiago: Librotecnia, 2007.

NOGUEIRA, Humberto, "Diálogo interjurisdiccional, control de convencionalidad y jurisprudencia del Tribunal Constitucional en período 2006-2011", Estudios Constitucionales, $\mathrm{N}^{\circ} 2$ (2012), pp. 57-140.

NOVOA, Eduardo, Curso de Derecho Penal Chileno. Parte general: Tomo I, Santiago: Editorial Jurídica de Chile, 2005. 
FERNÁNDEZ, José. "Los apremios personales en la jurisprudencia del Tribunal Constitucional: un análisis crítico desde la dogmática de los principios y límites penales".

VERDUGO, Mario, et al, Derecho Constitucional: Tomo I, Santiago: Editorial Jurídica de Chile, 1999. 